\title{
Silicate minerals control the potential uses of phosphorus-laden mineral-engineered biochar as phosphorus fertilizers
}

\author{
Natcha Sornhiran ${ }^{1} \cdot$ Surachet Aramrak ${ }^{1}$. Nattaporn Prakongkep ${ }^{2} \cdot$ Worachart Wisawapipat $^{1,3}$
}

Received: 7 July 2021 / Accepted: 19 October 2021

(c) The Author(s) 2022

\begin{abstract}
Silicate minerals constitute the main components in silicon ( $\mathrm{Si}$ )-rich biomass, affecting the phosphorus (P) adsorption and release competencies of mineral-engineered biochar; however, the mechanisms underlying their differences remain largely unresolved. To examine these interactions, we investigated the mineralogical compositions and quantified the P-adsorption capacities of Al-, Fe-, Mn-, Zn-, and Mg-engineered biochars from Si-rich rice husk material. The potential uses of P-laden mineral-engineered biochar for $\mathrm{P}$ fertilizers were assessed using citric acid extraction. The results from X-ray diffraction, scanning electron microscopy, and Fourier transform infrared spectrometry revealed that mixed metal (oxyhydr)oxides and metal-silicate compounds precipitated in the biochar structure and acted as the main P adsorbents. Micro-crystalline silicates derived from the biomass-induced metal-silicate precipitates in all engineered biochars, which effectively retained the aqueous $\mathrm{P}$ with varying excellent capacities (25.6-46.5 mg/g) but relatively slow kinetics (48 h). The suitability of the $\mathrm{Zn}-, \mathrm{Mg}-, \mathrm{Mn}-$, and Fe-biochars as P-recycled fertilizers was confirmed by the high amounts of citric acid extractable P (19-69\% of the total P). Varying amounts of $\mathrm{Zn}, \mathrm{Mg}$, and $\mathrm{Mn}$ (34-47\% of the total host metals) were also released from the engineered biochar through ligand-promoted dissolution. Our data shed light on the novel potential utilization of $\mathrm{Mn}$-, $\mathrm{Mg}$ - and Zn-biochars from Si-rich biomass for $\mathrm{P}$ retrieval and their use for $\mathrm{P}, \mathrm{Mg}$, and micronutrient ( $\mathrm{Mn}$ and $\mathrm{Zn}$ ) fertilizers. Regarding the $\mathrm{P}$ removal capacity, the mineral-engineered biochar needed a longer adsorption period than conventional metal-engineered biochar.
\end{abstract}

\section{Graphical Abstract}

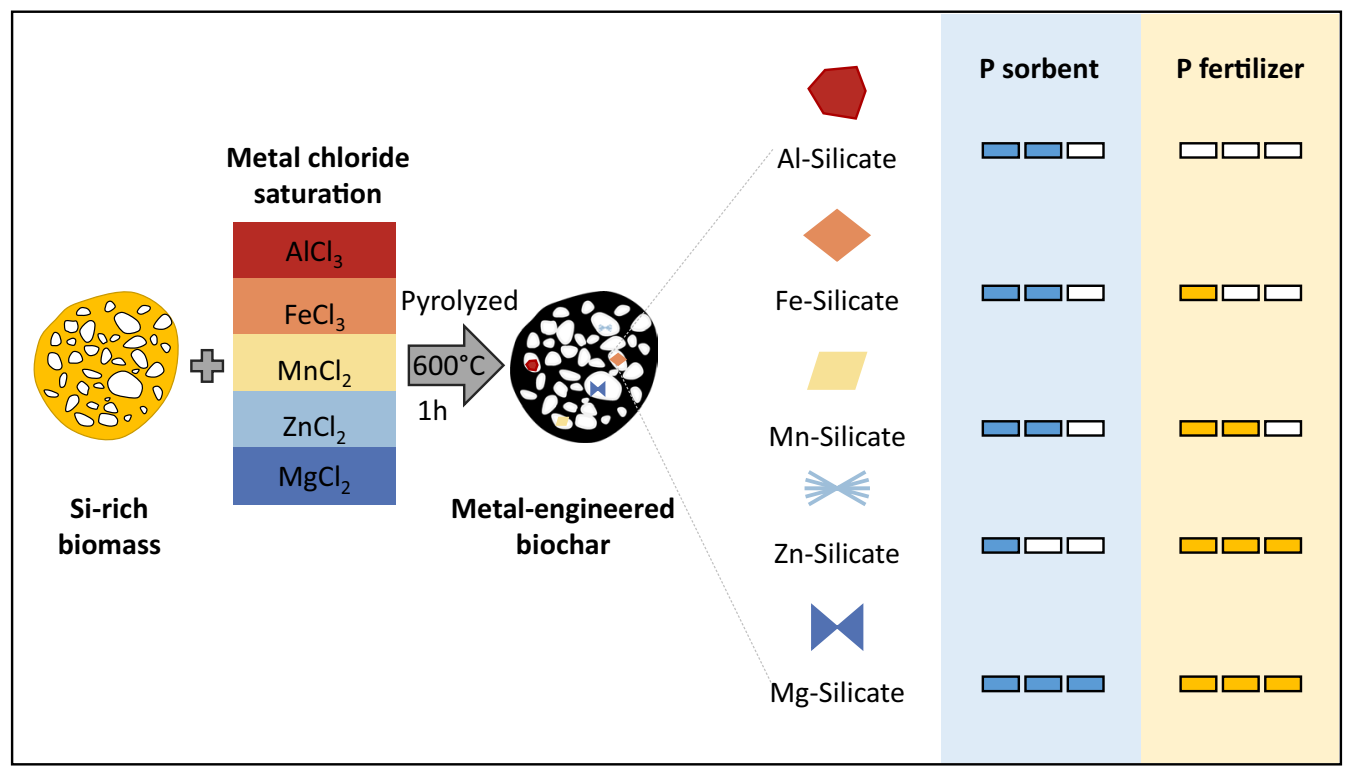

Extended author information available on the last page of the article 


\section{Highlights}

- Al-, Fe-, Mn-, Zn-, and Mg-engineered biochars have potential to reclaim aqueous $P$

- Silicon plays a pivotal role in $\mathrm{P}$ retention and release of metal-biochar composites
- Silicates promote potential use of biochar for P recycled fertilizer

Keywords Engineered biochar · Rice husk $\cdot$ Silicon $\cdot$ Waste management $\cdot$ Waste treatment

\section{Introduction}

Biochar utilization constitutes a clean and green technology for the effective recycling of biomass and organic wastes because it can purify pollutants from wastewater and aquatic environments (Ahmad et al. 2014). Biochar loaded with metal (oxyhydr)oxides-mineral-engineered biochar-has been recognized as an adsorbent that can improve the competency of biochar for contaminant removal. The competency for anionic pollutant retention is primarily controlled by the biomass type and added metals (El-Naggar et al. 2019; Mohan et al. 2018; Prakongkep et al. 2015). Many studies have loaded biochar with $\mathrm{Al}, \mathrm{Fe}, \mathrm{Mn}$, and $\mathrm{Mg}$ to form metal (oxyhydr)oxides to act as the main effective sorbents for enhancing their removal capacity (Luo et al. 2021; Peng et al. 2019; Takaya et al. 2016; Vikrant et al. 2018; Wang et al. 2015; Yang et al. 2019a; Zhang and Gao 2013). Mg-biochar has been studied the most for its potential use in $\mathrm{P}$ removal because of its high retention capacity $(95-835 \mathrm{mg} / \mathrm{g}$ ) and its subsequent regeneration as P-recycled fertilizer (Takaya et al. 2016; Yao et al. 2013). Recent research also showed that higher loadings of $\mathrm{MgO}$ to biochar changed the $\mathrm{Mg}-\mathrm{O}$ nanocomposite and enhanced $\mathrm{P}$ retention (Luo et al. 2021). Other adsorbents such as montmorillonitebiochar and zinc/aluminum layered double hydroxides ( $\mathrm{Zn} /$ Al-LDH) showed excellent $\mathrm{P}$ sorption capacity of about $150 \mathrm{mg} / \mathrm{g}$ (Chen et al. 2017; Yang et al. 2019a).

Biochar engineering with $\mathrm{Al}, \mathrm{Fe}, \mathrm{Mn}$, and $\mathrm{Zn}$ has also been investigated with the main interest being the removal of phosphate, nitrate, arsenate, or arsenite. For example, Albiochar from diverse biomass had various high $\mathrm{P}$ removal capacities of 16-135 mg/g (Zhang and Gao 2013; Zheng et al. 2020). Some studies revealed that Fe-biochar from diverse feedstocks had reasonable $\mathrm{P}$ retention of up to $11 \mathrm{mg} / \mathrm{g}$ (Takaya et al. 2016; Zheng et al. 2020). Recent studies showed that Fe/Al biochars retained P up to $215 \mathrm{mg} / \mathrm{g}$ (Peng et al. 2019; Sornhiran et al. 2021). To our knowledge, there has been no investigation on Mn-biochar for use as a $\mathrm{P}$ adsorbent, although in an arsenate sorption study it was reported to have low arsenate retention capacity of $0.59 \mathrm{mg} / \mathrm{g}$ (Wang et al. 2015). A study using Zn-biochar for
P removal reported a maximum retention of only $5.1 \mathrm{mg} / \mathrm{g}$ (Namasivayam and Sangeetha 2004).

Very limited studies have examined Al-, Fe-, Mn-, and $\mathrm{Zn}$ - engineered biochars and reused them as P-recycled fertilizers, attributed to $\mathrm{Fe}$ and $\mathrm{Al}$ oxides showing a strong binding capacity towards $\mathrm{P}$ and thus lowering $\mathrm{P}$ release (Peng et al. 2021). A very recent study revealed the possible use of $\mathrm{Fe}$ - and Al-biochars for P-recycled fertilizers as they could release adequate available $\mathrm{P}$ concentrations to sand material (Sornhiran et al. 2021). Most importantly, Fe, Mn, and $\mathrm{Zn}$ are plant micronutrients; however, the production of the micronutrient-biochars as a $\mathrm{P}$ adsorbents and their regeneration as both $\mathrm{P}$ - and micronutrient-recycled fertilizers that potentially offer a greener and cleaner technology for environmental sustainability are unresolved.

Rice husk is a promising agricultural residue for biochar production; globally approximately 140 million t, is generated annually (Moraes et al. 2014; Shen 2017). Silicate compounds in such biomass can substantially affect the adsorption and release properties of the mineral-engineered biochar. Amorphous silicates with high solubility in the biomass could polymerize or coprecipitate with metal (oxyhydr)oxides (Christl et al. 2012) and might decrease the efficiency of mineral-engineered biochar for P reclamation. Such evidence might unintentionally support a belief that Si-rich material is unsuitable for preparing engineered biochars for P removal, resulting in it simply not to being used as biochar feedstock. Contrariwise, we hypothesized that the polymerization and coprecipitation mechanisms between metal (oxyhydr)oxides and silicates could offer additional benefits by enhancing $P$ release from adsorbents with strong $\mathrm{P}$-adsorption bonding energy with $\mathrm{Al}, \mathrm{Fe}, \mathrm{Mn}$, and $\mathrm{Zn}$-engineered biochars, and thereby further promote their potential reuse as P-recycled fertilizers rather than being used solely as $\mathrm{P}$ adsorbents. To date, key information remains seriously lacking on the P-sorption capacity and the possible use of engineered biochar after $\mathrm{P}$ addition (P-laden biochar) from Si-rich material for P-recycled fertilizers.

Therefore, this research aimed: (i) to investigate the capacity and suitable $\mathrm{pH}$ conditions of Al-, Fe-, Mn-, Zn-, and $\mathrm{Mg}$-biochars prepared from rice husk for $\mathrm{P}$ removal and (ii) to assess the $\mathrm{P}$ and metal extractability of the 
mineral-engineered biochars for potential uses as combined $\mathrm{P}$ and micronutrient fertilizers using citric acid. This organic acid is the most common extractant for assessing P fertilizer potential use and is the acid released from plant roots to promote $\mathrm{P}$ and micronutrient availability through ligandpromoted dissolution (Mizuki and Katoh 2021; Yang et al. 2019b)

\section{Materials and methods}

\subsection{Preparation of pristine and mineral-engineered biochars}

Rice husk, as one of the primary agricultural residues in several rice-producing countries around the world, was selected for biochar production. The pristine biochar (PB) was produced as described by Klüpfel et al. (2014); this procedure has proved to successfully obtain biochar with excellent chemical activity. Briefly, the intact raw material was air-dried, tightly packed into a heat-resistant crucible $(35 \mathrm{~mL})$ to minimize oxygen diffusion and then placed in a muffle furnace (Carbolite 91E; Carbolite; UK) preheated at $600{ }^{\circ} \mathrm{C}$. The closed vessel was carbonized under an ambient atmosphere for $1 \mathrm{~h}$ before removal and colling in a desiccator before further analyses.

The pretreatment process was selected for mineralengineered biochar production since many studies reported that this method provided higher P-retention capacity than the post-treatment process (Takaya et al. 2016). The mineral-engineered biochars were produced as described by Zhang et al. (2012) with some modifications. About $10 \mathrm{~g}$ samples of the air-dried biomass were individually saturated with $60 \mathrm{~mL}$ each of $\mathrm{AlCl}_{3}, \mathrm{FeCl}_{3}, \mathrm{MnCl}_{2}, \mathrm{ZnCl}_{2}$, and $\mathrm{MgCl}_{2}(67 \% \mathrm{w} / \mathrm{v})$. The equilibrium periods varied between 48 and $72 \mathrm{~h}$, depending on the saturation of each metaltreated biomass. The metal-impregnated biomass was oven-dried at $80^{\circ} \mathrm{C}$ for at least $24 \mathrm{~h}$ and carbonized using the same procedure as for $\mathrm{PB}$ production. The $\mathrm{PB}$ and mineral-engineered biochar samples were washed several times with deionized water to remove impurities and were dried at $80{ }^{\circ} \mathrm{C}$ for $24 \mathrm{~h}$. All samples were finely ground using an agate mortar and passed through a $0.5-2.0 \mathrm{~mm}$ sieve. The resultant material was collected and preserved in an airtight container for further investigation. The engineered biochar samples treated with $\mathrm{Al}, \mathrm{Fe}, \mathrm{Mn}, \mathrm{Zn}$, and $\mathrm{Mg}$ were designated as $\mathrm{EB}_{\mathrm{Al}}, \mathrm{EB}_{\mathrm{Fe}}, \mathrm{EB}_{\mathrm{Mn}}, \mathrm{EB}_{\mathrm{Zn}}$, and $\mathrm{EB}_{\mathrm{Mg}}$, respectively.

\subsection{Characterization of pristine, metal-engineered, and phosphorus-laden biochars}

The mineral and chemical compositions and physical properties of all engineered biochar and P-laden biochar samples were analyzed using X-ray diffraction (XRD), Fourier transform infrared spectrometry (FTIR), scanning electron microscopy (SEM) imaging, acid digestion, and physisorption analysis. The powder XRD patterns of all biochar samples were collected using a PANalytical X-ray diffractometer equipped with $\mathrm{Cu} \mathrm{K} \alpha$ radiation $(\mathrm{k}=1.54059 \AA)$ over the range $5-70^{\circ} 2 \theta$, using a step size of $0.015^{\circ} 2 \theta$, and a dwell time of $0.02^{\circ} 2 \theta / \mathrm{s}$. The FTIR spectra were recorded in the $4000-400 \mathrm{~cm}^{-1}$ region with a resolution of $2 \mathrm{~cm}^{-1}$ using an FTIR spectrometer (Bruker Tensor 27; Bruker; USA). The size, shape, and chemical composition of minerals (oxides and phosphate compounds) in the mineral-engineered biochar and P-laden biochar were investigated in detail using SEM (JEM-2010 (HR); JEOL; Japan) combined with energy-dispersive X-ray spectrometry (EDS; Oxford Instruments; UK). The total $\mathrm{P}$ in the samples was quantified based on digestion of $0.20 \mathrm{~g}$ finely ground samples with $12 \mathrm{~mL}$ of a mixture of 1:3 hydrochloric acid $(\mathrm{HCl})$ : nitric acid $\left(\mathrm{HNO}_{3}\right.$; aqua regia) at $130{ }^{\circ} \mathrm{C}$ for $3 \mathrm{~h}$ (Chen and Ma 2001). The inorganic P concentration in the digests was colorimetrically measured using a spectrophotometer. The specific surface area was analyzed using the Brunauer-Emmett-Teller (BET) method on an adsorption analyzer (3Flex Physisorption; Micromeritics; USA) with the volume and size (mesopore $=2-150 \mu \mathrm{m}$; and micropore $=<2 \mu \mathrm{m}$ ) of pores calculated from the respective Density Functional Theory and Barrett-JoynerHalenda analysis.

\subsection{Determination of zeta potential of pristine and mineral-engineered biochars}

The zeta potential was measured following the procedure of Szewczuk-Karpisz et al. (2020) to investigate the surface charge behavior of the PB and EB samples. Briefly, the samples were ground to pass through a $0.053 \mathrm{~mm}$ sieve. About $40 \mathrm{mg}$ of the solid was mixed with $400 \mathrm{~mL}$ of $1 \mathrm{mM}$ $\mathrm{NaCl}$ solution. The suspension $\mathrm{pH}$ value of each sample was adjusted to 2.0-10.0 using $\mathrm{HCl}$ and $\mathrm{NaOH}$, and the samples were equilibrated for 3 days. The zeta potential was determined using a Zetasizer instrument (Zetasizer nano series; Malvern Panalytical; UK). The plot between the suspension $\mathrm{pH}$ and zeta potential of the biochar was used to identify the isoelectric point (IEP). 


\subsection{Phosphorus sorption of mineral-engineered biochar}

\subsubsection{Sorption isotherm}

The P-sorption isotherms of all biochar samples ( $\mathrm{PB}, \mathrm{EB}_{\mathrm{Al}}$, $\mathrm{EB}_{\mathrm{Fe}}, \mathrm{EB}_{\mathrm{Mn}}, \mathrm{EB}_{\mathrm{Zn}}$, and $\mathrm{EB}_{\mathrm{Mg}}$ ) were performed in triplicate. Solid materials were weighed in separate centrifuge tubes and mixed with varying $\mathrm{P}$ concentrations of $\mathrm{KH}_{2} \mathrm{PO}_{4}$ $(20-500 \mathrm{mg} / \mathrm{L})$ using a solid-to-solution ratio of 1:500. The vials were agitated on a mechanical shaker at room temperature $\left(25 \pm 2{ }^{\circ} \mathrm{C}\right)$ for $24 \mathrm{~h}$. The aliquots were kept after centrifugation at $2205 \times g$ for $15 \mathrm{~min}$ for $\mathrm{P}$ analysis and metal analyses, as described above. Details of the Langmuir and Freundlich's models are given in supporting information.

\subsubsection{Sorption kinetics}

The P-sorption kinetics were investigated to obtain information on how quickly the mineral-engineered biochars retained the dissolved P. Each mineral-engineered biochar was weighed into a centrifuge tube with the $\mathrm{P}$ solution at the defined the $\mathrm{P}$ sorption maximum $(\mathrm{Qm})$ concentration. The experiment was run in triplicate. The vials were agitated on a mechanical shaker at room temperature $\left(25 \pm 2{ }^{\circ} \mathrm{C}\right)$ for periods of up to $72 \mathrm{~h}$. After defined periods of 1, 2, 4, 6, 12, 24,48 , and $72 \mathrm{~h}$, the aliquots were retrieved after centrifugation and preserved for $\mathrm{P}$ analysis and metal analyses. Details of the kinetics models are given in supporting information.

\subsubsection{Sorption envelope}

The P-sorption envelope was determined on the mineralengineered biochar samples to obtain the suitable $\mathrm{pH}$ conditions for maximizing $\mathrm{P}$ removal. Each mineral-engineered biochar sample was weighed into a centrifuge tube containing the $\mathrm{P}$ solution at the $Q m$ concentration and was adjusted to $\mathrm{pH} 4.0 \pm 0.02,6.0 \pm 0.02$, and $8.0 \pm 0.02$ using $\mathrm{HCl}$ or $\mathrm{NaOH}$. The vessels were equilibrated using a mechanical shaker at room temperature $\left(25 \pm 2{ }^{\circ} \mathrm{C}\right)$ for defined periods of $1,2,4,6,12,24,48$, and $72 \mathrm{~h}$. The supernatants were collected for $\mathrm{P}$ analysis after centrifugation at $2205 \times g$ for $15 \mathrm{~min}$

\subsection{Phosphorus release of phosphorus-laden biochar}

All mineral-engineered biochar samples were treated with different $\mathrm{P}$ concentrations and solution $\mathrm{pH}$ values to obtain approximately $10 \%$ of their $Q m$ concentration. The defined concentrations were expected to obtain the $\mathrm{P}$ contents in $\mathrm{P}$-laden biochar after $\mathrm{P}$ retrieval from real wastewaters containing 0.9-6.4 mg P/L with a 1:500 solid-to-solution ratio (Zheng and Gao 2019). The sample aliquots were equilibrated using a mechanical shaker for $48 \mathrm{~h}$ before centrifugation at $2205 \times g$ for $15 \mathrm{~min}$ and then heated at $80{ }^{\circ} \mathrm{C}$. All engineered biochar samples $\left(\mathrm{EB}_{\mathrm{Al}}, \mathrm{EB}_{\mathrm{Fe}}, \mathrm{EB}_{\mathrm{Mn}}, \mathrm{EB}_{\mathrm{Zn}}\right.$, and $\left.\mathrm{EB}_{\mathrm{Mg}}\right)$ were designated as P-laden biochar $\left(\mathrm{EB}_{\mathrm{Al}-\mathrm{P}}, \mathrm{EB}_{\mathrm{Fe}-\mathrm{P}}\right.$, $E_{M n-P}, E B_{Z n-P}$, and $\left.E B_{M g-P}\right)$. The pH values of the P-laden biochar samples were measured using a $\mathrm{pH}$ meter at a solidto-solution ratio of 1:20.

Citric acid extraction was selected to obtain the capacity of $\mathrm{P}$ released from the P-laden biochar samples because this solution has been widely accepted for considering the potential of biochar as P fertilizer (Weber et al. 2014). In addition, citric acid is an organic acid commonly released from plant roots to enhance the acquisition of $\mathrm{P}$ and micronutrients (Bais et al. 2006). The P-laden biochar was mixed with $2 \%$ citric acid (w/v) with a solid-to-solution of 1:100. The tubes were agitated on a shaker at $25 \pm 2{ }^{\circ} \mathrm{C}$ for $30 \mathrm{~min}$. The supernatants were kept, and the $\mathrm{P}$ concentrations in the aliquots were colorimetrically analyzed using spectrophotometry. The experiment was run in triplicate.

\section{Results and discussion}

\subsection{Characterization of pristine, metal-engineered, and phosphorus-laden biochars}

\subsubsection{BET analysis}

The BET properties of the biochars are given in Table 1 . Impregnating biomass with $\mathrm{Al}, \mathrm{Fe}, \mathrm{Mn}, \mathrm{Zn}$, or $\mathrm{Mg}$ increased the mesopore area, cumulative pore volume, and median pore size of the engineered biochar samples relative to the pristine biochar. The lowest specific surface area value was for $\mathrm{EB}_{\mathrm{Mg}}\left(246 \mathrm{~m}^{2} / \mathrm{g}\right)$, and the highest value was for $\mathrm{EB}_{\mathrm{Zn}}$ $\left(848 \mathrm{~m}^{2} / \mathrm{g}\right)$. The extraordinarily high specific surface area of the $\mathrm{EB}_{\mathrm{Zn}}$ was attributed to the preferred formation of $\mathrm{Zn}$ silicate with large crystal sizes $(>10 \mu \mathrm{m})$ (Figs. 1,2) and thereby contributing solely to the mesopore area. Notably, the biochar engineering with metals promoted the mesopore area formation, which was 51-898\% higher than that in the PB sample. Biochar engineering with metals increased both the cumulative pore volume $\left(0.142-1.421 \mathrm{~cm}^{3} / \mathrm{g}\right.$ or $213-3058 \%$ of the PB value) and median pore width (0.47-0.77 nm, or 9-79\% of the PB value) compared to the respective $P B$ samples $\left(0.045 \mathrm{~cm}^{3} / \mathrm{g}\right.$ and $\left.0.43 \mathrm{~nm}\right)$.

\subsubsection{XRD and chemical analysis}

While quartz and calcite were the major minerals in the PB sample (Fig. S1), many metal-(oxyhydr)oxides and 
metal-silicate compounds dominated in all the mineralengineered biochar samples $\left(\mathrm{EB}_{\mathrm{Al}}, \mathrm{EB}_{\mathrm{Fe}}, \mathrm{EB}_{\mathrm{Mn}}, \mathrm{EB}_{\mathrm{Zn}}\right.$, and $\mathrm{EB}_{\mathrm{Mg}}$ ) after the rice husk had been treated with the metals (Fig. 1). Boehmite (AlOOH) was the sole Al (oxyhydr)oxide in the $\mathrm{EB}_{\mathrm{Al}}$ sample, while various amounts of $\mathrm{Fe}$ (oxyhydr)oxides, including hematite $\left(\alpha-\mathrm{Fe}^{\mathrm{III}}{ }_{2} \mathrm{O}_{3}\right)$, magnetite $\left(\alpha-\mathrm{Fe}^{\mathrm{II}} \mathrm{Fe}^{\mathrm{III}}{ }_{2} \mathrm{O}_{4}\right)$, amakinite $\left(\mathrm{Fe}^{\mathrm{II}}[\mathrm{OH}]_{2}\right)$, and cronstedtite $\left(\mathrm{Fe}_{2}{ }_{2} \mathrm{Fe}^{\mathrm{III}}\left(\left[\mathrm{SiFe}^{\mathrm{III}}\right] \mathrm{O}_{4}[\mathrm{OH}]_{5}\right)\right.$ were present in the $\mathrm{EB}_{\mathrm{Fe}}$ sample. Manganite $\left(\mathrm{Mn}^{\mathrm{III}} \mathrm{O}[\mathrm{OH}]\right)$, kanoite $\left(\mathrm{Mn}^{\mathrm{II}}\left[\mathrm{SiO}_{3}\right]\right)$, and quartz occurred in the $\mathrm{EB}_{\mathrm{Mn}}$ sample. Willemite $\left(\mathrm{Zn}_{2} \mathrm{SiO}_{4}\right)$ and $\mathrm{K}_{2} \mathrm{Zn}\left(\mathrm{SO}_{4}\right)_{2}$ were found in the $\mathrm{EB}_{\mathrm{Zn}}$ sample, while periclase $(\mathrm{MgO})$, brucite $\left(\mathrm{Mg}(\mathrm{OH})_{2}\right)$, and sepiolite $\left.\left[\mathrm{Mg}_{4} \mathrm{Si}_{6} \mathrm{O}_{15}(\mathrm{OH})_{2} \cdot 6 \mathrm{H}_{2} \mathrm{O}\right)\right]$ were observed in the $\mathrm{EB}_{\mathrm{Mg}}$ sample.

There were no metal phosphate compounds detected in any P-laden biochar samples using the XRD technique (Fig. 1). This was attributable to the P loading being only about $10 \%$ of the P-sorption maximum capacity for each engineered biochar, which suggested that the metal-phosphate compounds were formed in low quantities below the detection limit $(0.2-5 \%)$ of the conventional XRD technique for minerals with a good crystalline structure (Newman et al. 2015).

The total $\mathrm{P}$ concentrations in the P-laden biochar were in the range $2.38-3.89 \mathrm{mg} / \mathrm{g}$, with the lowest and highest values for $\mathrm{EB}_{\mathrm{Zn}-\mathrm{P}}$ and $\mathrm{EB}_{\mathrm{Al}-\mathrm{P}}$, respectively (Table $\mathrm{S} 1$ ). Most engineered biochar samples after $\mathrm{P}$ loading were acidic with the range in $\mathrm{pH}$ values covering very strongly acidic for $\mathrm{EB}_{\mathrm{Fe}-\mathrm{P}}(\mathrm{pH}=4.37)$, strongly acidic for $\mathrm{EB}_{\mathrm{Zn}-\mathrm{P}}$ $(\mathrm{pH}=5.51)$, and moderately acidic for $\mathrm{EB}_{\mathrm{Mn}-\mathrm{P}}(\mathrm{pH}=5.65)$ and $\mathrm{EB}_{\mathrm{Al}-\mathrm{P}}(\mathrm{pH}=5.86)$. Only $\mathrm{EB}_{\mathrm{Mg}-\mathrm{P}}$ had a neutral $\mathrm{pH}$ value $(\mathrm{pH}=7.34)$.

\subsubsection{SEM analysis}

The engineered and P-laden biochar samples were examined in detail using the SEM-EDS technique. The SEM-EDS data showed diverse types, sizes, and shapes of metal compounds in the engineered biochar (Fig. 2), and the corresponding P-laden biochar samples (Fig. 3) were primarily governed by the added metals and $\mathrm{Si}$ compounds in the raw material. In addition to the XRD data, the SEM-EDS analysis provided new information that most of the metal (oxyhydr)oxides in the engineered biochar occurred as different crystals of metal-silicate mixtures, including Al-silicate (anhedral), Fe-silicate (compact granular), Mn-silicate (cubic), Zn-silicate (straw-bundle-like), and Mg-silicate (anhedral stack). The information suggested that the engineered metals were likely to react with dissolved microcrystalline Si minerals in the raw rice husk biomass during the metal saturation process, which could be newly precipitated as metal-silicate compounds upon pyrolysis. The particle sizes of the metal silicate compounds from the SEM analysis were typically smaller than $1 \mu \mathrm{m}$ for the $\mathrm{EB}_{\mathrm{Al}}, \mathrm{EB}_{\mathrm{Fe}}, \mathrm{EB}_{\mathrm{Mn}}$, and $\mathrm{EB}_{\mathrm{Mg}}$ samples, but those for the $\mathrm{EB}_{\mathrm{Zn}}$ samples were larger than $10 \mu \mathrm{m}$.

Although metal silicate mixtures were undetectable using XRD, the SEM-EDS analysis demonstrated that they were the primary adsorbents for $\mathrm{P}$ (Fig. 3). The particle shapes of the P-metal-silicate compounds noticeably differed from those of the engineered biochars. The particle sizes of the P-metal-silicate mixtures were also smaller than those of the mineral-engineered biochars. The data suggested that the dissolution of metal-oxide and metal-silicate compounds and their subsequent coprecipitation with the added $\mathrm{P}$ could be the main mechanism for $\mathrm{P}$ retention within the engineered biochar structure, in addition to the electrostatic attraction mechanism during the $\mathrm{P}$ adsorption process.

\subsubsection{FTIR analysis}

The FTIR spectrum of the PB sample indicated the presence of $\mathrm{Si}-\mathrm{O}-\mathrm{Si}$, aliphatic $\mathrm{CH}_{2}$, and aromatic $\mathrm{C}=\mathrm{C}$ and $\mathrm{C}=\mathrm{O}$ functional groups (Fig. 4). For all metal engineered biochar samples, the intensity of the bands in the carboxylate region $\left(1700-1400 \mathrm{~cm}^{-1}\right)$, particularly the peaks at 1441 , 1561 , and $1651 \mathrm{~cm}^{-1}$, became more intense relative to the PB sample, suggesting that carboxylic functional groups

Table 1 BET analysis of pristine biochar (PB) and Al-, Fe, Mn-, Zn-, and Mg-engineered biochars from rice husk treated with Al, Fe, Mn, Zn, and $\mathrm{Mg}\left(\mathrm{EB}_{\mathrm{Al}}, \mathrm{EB}_{\mathrm{Fe}}, \mathrm{EB}_{\mathrm{Mn}}, \mathrm{EB}_{\mathrm{Zn}}\right.$, and $\left.\mathrm{EB}_{\mathrm{Mg}}\right)$ Values in parenthesis indicate the change in properties of each sample relative to the $\mathrm{PB}$ sample

\begin{tabular}{|c|c|c|c|c|c|c|c|}
\hline Sample & $\begin{array}{l}\text { Specific surface } \\
\text { area } \\
\left(-\mathrm{m}^{2} / \mathrm{g}-\right.\end{array}$ & Micropore area & Mesopore area & $\begin{array}{l}\text { Relative mesopore } \\
\text { area } \\
(\% \text { of total })\end{array}$ & $\begin{array}{l}\text { Cumulative pore } \\
\text { volume } \\
\left(\mathrm{cm}^{3} / \mathrm{g}\right)\end{array}$ & $\begin{array}{l}\text { Average pore } \\
\text { diameter } \\
(-\mathrm{nm}-)\end{array}$ & Median pore width \\
\hline $\mathrm{PB}$ & 255 & 170 & 85 & 33 & 0.045 & 5.11 & 0.43 \\
\hline $\mathrm{EB}_{\mathrm{Al}}$ & $341(34)$ & $40(-76)$ & $301(254)$ & 88 & $0.258(473)$ & $4.69(-8)$ & $0.59(37)$ \\
\hline $\mathrm{EB}_{\mathrm{Fe}}$ & $290(14)$ & $163(-4)$ & $128(51)$ & 44 & $0.158(251)$ & $8.60(68)$ & $0.47(9)$ \\
\hline $\mathrm{EB}_{\mathrm{Mn}}$ & $299(17)$ & $124(-27)$ & $175(106)$ & 59 & $0.137(204)$ & $4.34(-15)$ & $0.50(16)$ \\
\hline $\mathrm{EB}_{\mathrm{Zn}}$ & $848(233)$ & $0(-100)$ & $848(898)$ & 100 & $1.421(3,058)$ & $6.86(34)$ & $0.77(79)$ \\
\hline $\mathrm{EB}_{\mathrm{Mg}}$ & $246(-4)$ & $106(-38)$ & $140(140)$ & 57 & $0.141(213)$ & $5.62(10)$ & $0.50(16)$ \\
\hline
\end{tabular}




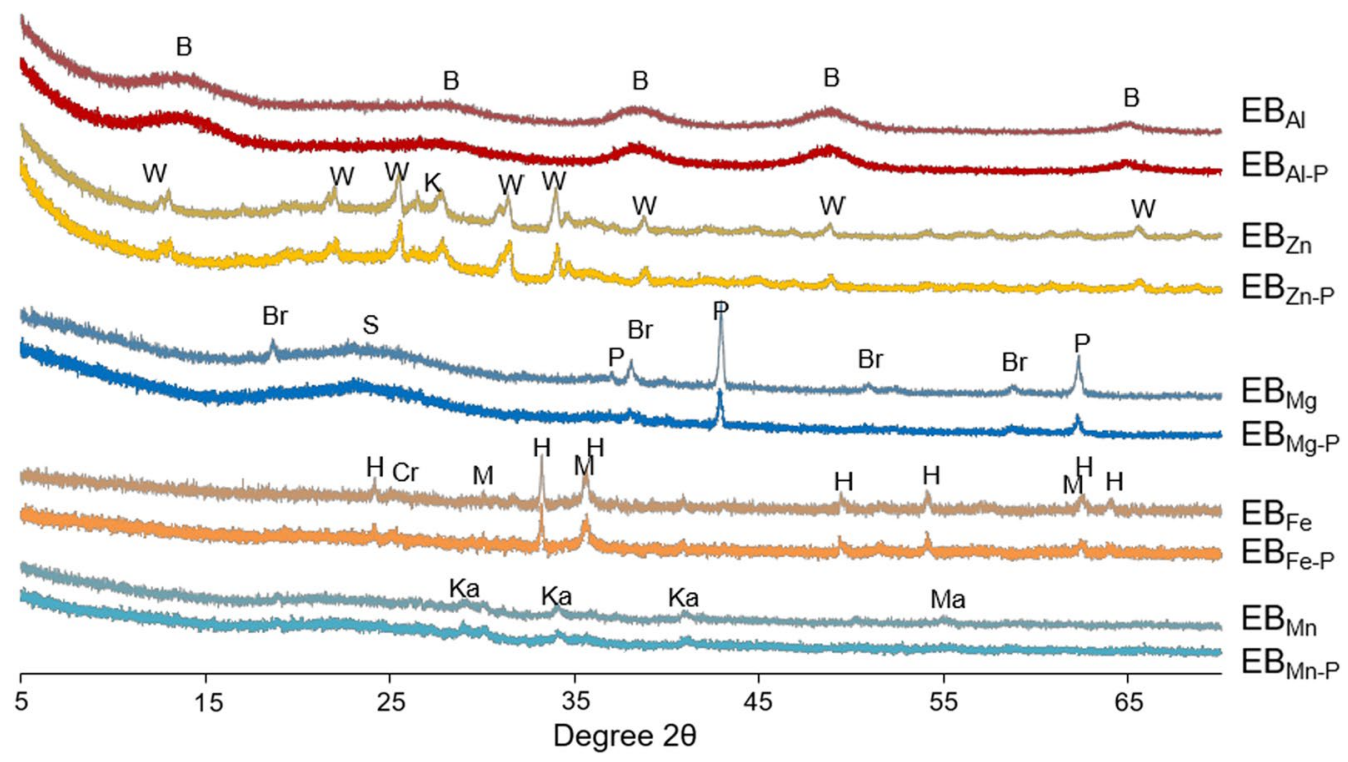

Fig. 1 X-ray diffraction patterns of engineered (E) and P-laden (-P) biochars produced from rice husk pyrolyzed at $600{ }^{\circ} \mathrm{C} . B$ boehmite, $W$ willemite, $\mathrm{K} \mathrm{K}_{2} \mathrm{Zn}\left(\mathrm{SO}_{4}\right)_{2}$, $\mathrm{Br}$ brucite, $S$ sepiolite, $P$ periclase, $H$ hematite, $M$ magnetite, $C r$ cronstedtite, $M a$ manganite, $K a$ kanoite

could be a primary adsorption site for the added Al, Fe, $\mathrm{Mn}, \mathrm{Zn}$, and $\mathrm{Mg}$. The broad peak at $482 \mathrm{~cm}^{-1}$ for all the engineered biochar samples was less intense than that for the PB sample, which could be interpreted as the dissolution of polymeric silicates from the engineered biochar. The band of $\mathrm{Si}-\mathrm{O}-\mathrm{Si}$ at $742 \mathrm{~cm}^{-1}$ was more pronounced in some engineered biochar samples $\left(\mathrm{EB}_{\mathrm{Al}}, \mathrm{EB}_{\mathrm{Al}-\mathrm{P}}, \mathrm{EB}_{\mathrm{Mn}}\right.$, and $\left.\mathrm{EB}_{\mathrm{Mn}-\mathrm{P}}\right)$, which may indicated the coprecipitation of the metal with silicates. The broad peak at around $600 \mathrm{~cm}^{-1}$ was assigned to $\mathrm{Al}-\mathrm{O}$ bonding being visible in the $\mathrm{EB}_{\mathrm{Al}}$ sample (Thabet and Ismaiel 2016). The small peak at $850 \mathrm{~cm}^{-1}$ in the $\mathrm{EB}_{\mathrm{Mg}}$ and $\mathrm{EB}_{\mathrm{Mg}}-\mathrm{P}$ samples corresponded to $\mathrm{Mg}-\mathrm{O}$ bonding (Akgul et al. 2019). The small peaks that occurred at $1250 \mathrm{~cm}^{-1}$ in all P-laden biochars could be interpreted as the symmetric vibrations of metaphosphate formation (El Batal et al. 2016). Additionally, the region around $800-1200 \mathrm{~cm}^{-1}$ indicated the presence of $\mathrm{PO}_{4}^{-3}$ (Arai and Sparks 2001) and the presence of the peak at about $3450 \mathrm{~cm}^{-1}$ (data not shown) indicated the $\mathrm{OH}$ stretching of free water molecules, which coincided with the high water level of carbon-coated montmorillonite nanocomposite (Wei et al. 2019).

\subsubsection{Zeta potential analysis}

Potentiometric titration data for the pristine and mineralengineered biochar samples are given in Fig. 5. The zeta potential of all biochar samples became more negative with increasing suspension $\mathrm{pH}$, which indicated the more negatively charged sites were on solid surfaces. The IEP value of the PB sample was 2.80, which was close to the point of zero charge (PZC) of quartz (Essington 2015). This value was lower than that for other EB samples. The IEP values of the EB samples increased in the order $\mathrm{EB}_{\mathrm{Mn}}(2.84)<\mathrm{EB}_{\mathrm{Mg}}$ (3.63) $<\mathrm{EB}_{\mathrm{Zn}}(4.54)<\mathrm{EB}_{\mathrm{Fe}}(4.90)<\mathrm{EB}_{\mathrm{Al}}(8.45)$, which were in strong accordance with their mineralogical compositions, showing the presence of metal silicates including kanoite, sepiolite, willemite, and cronstedtite in the respective $\mathrm{EB}_{\mathrm{Mn}}$, $\mathrm{EB}_{\mathrm{Mg}}, \mathrm{EB}_{\mathrm{Zn}}$, and $\mathrm{EB}_{\mathrm{Fe}}$ samples and boehmite in the $\mathrm{EB}_{\mathrm{Al}}$ sample (Fig. 1). These data demonstrated that the silicate compounds in the biomass did play an important role in changing the chemical composition and particle charge behavior.

\subsection{Phosphorus sorption of mineral-engineered biochar}

\subsubsection{Adsorption isotherms}

The maximum P-adsorption capacities of all the engineered biochar samples were higher than that for the pristine biochar (Table 2). The P sorption data were well described by both the Langmuir and Freundlich models with coefficient of determination $\left(\mathrm{R}^{2}\right)$ values in the ranges 0.72-0.99 (mean $=0.91)$ and 0.65-0.97 (mean $=0.89)$, respectively (Fig. 6). The $\mathrm{EB}_{\mathrm{Mg}}$ sample was the most effective engineered biochar for aqueous-P removal with a maximum sorption capacity of $46.5 \mathrm{mg} / \mathrm{g}$, followed by the $\mathrm{EB}_{\mathrm{Mn}}$ sample that adsorbed $\mathrm{P}$ up to $38.6 \mathrm{mg} / \mathrm{g}$. The $\mathrm{EB}_{\mathrm{Al}}$ and $\mathrm{EB}_{\mathrm{Fe}}$ samples retained comparable $\mathrm{P}$ quantities of 32.3 and $31.7 \mathrm{mg} / \mathrm{g}$, respectively. The $\mathrm{EB}_{\mathrm{Zn}}$ sample had the lowest $\mathrm{P}$ maximum sorption capacity of $25.6 \mathrm{mg} / \mathrm{g}$. The Langmuir $K_{L}$ coefficient (relating to P-binding energy) varied considerably from 
Fig. 2 Backscattered electron micrographs using SEM-EDS of engineered biochars from rice husk pyrolyzed at $600{ }^{\circ} \mathrm{C}$ showing metal-silicate mixtures of $\mathrm{EB}_{\mathrm{Al}}(\mathbf{a}), \mathrm{EB}_{\mathrm{Fe}}(\mathbf{b}), \mathrm{EB}_{\mathrm{Mn}}(\mathbf{c})$, $\mathrm{EB}_{\mathrm{Zn}}(\mathbf{d})$, and $\mathrm{EB}_{\mathrm{Mg}}(\mathbf{e})$. Small orange squares represent the area of SEM-EDS analysis. Atomic ratios: $\mathrm{Al}: \mathrm{Si} \approx 1.0: 1.7$, $\mathrm{Fe}: \mathrm{Si} \approx 1.0: 1.7, \mathrm{Mn}: \mathrm{Si} \approx$ 1.0:0.2, $\mathrm{Zn:Si} \approx 1.0: 0.4$, and $\mathrm{Mg}: \mathrm{Si} \approx 1.0: 0.2$ a

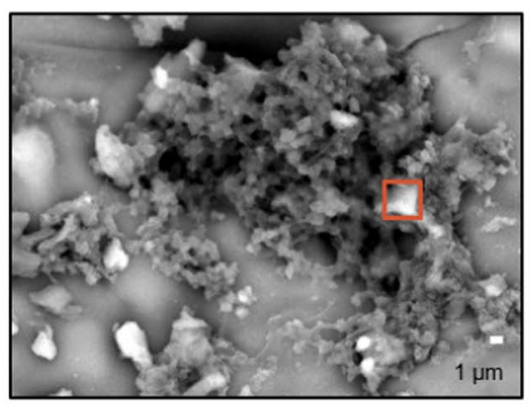

b

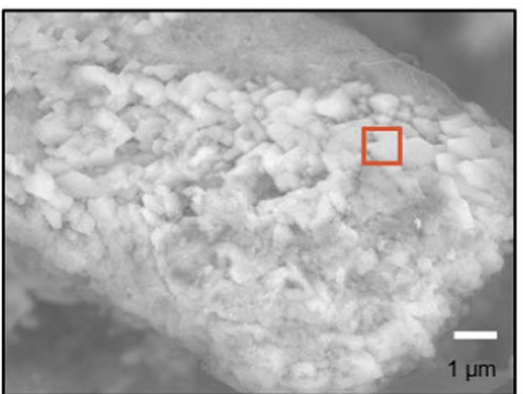

C

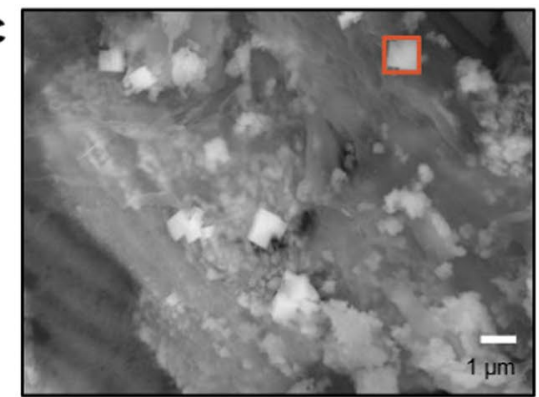

d

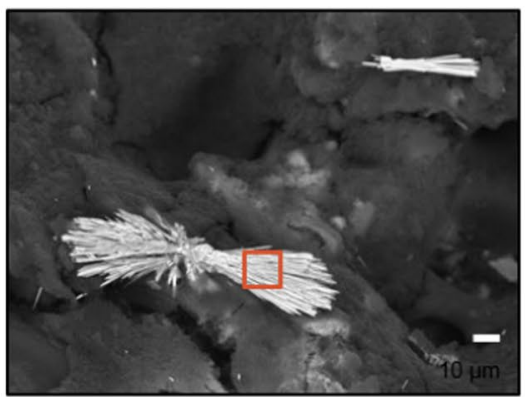

e

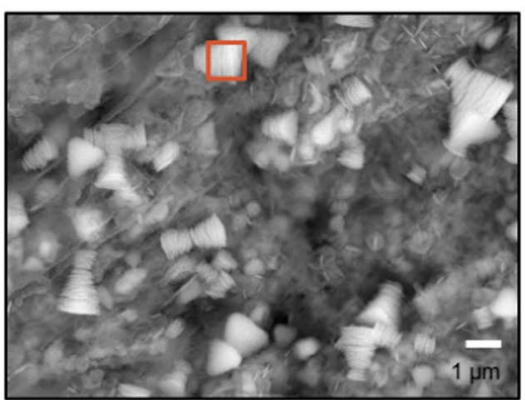

$q$

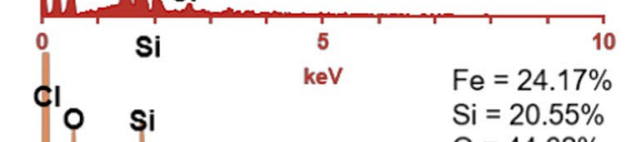

$\mathrm{Al}=7.57 \%$

$\mathrm{Si}=13.53 \%$

$\mathrm{O}=28.25 \%$

$\mathrm{Si}=20.55 \%$

$\mathrm{O}=44.62 \%$
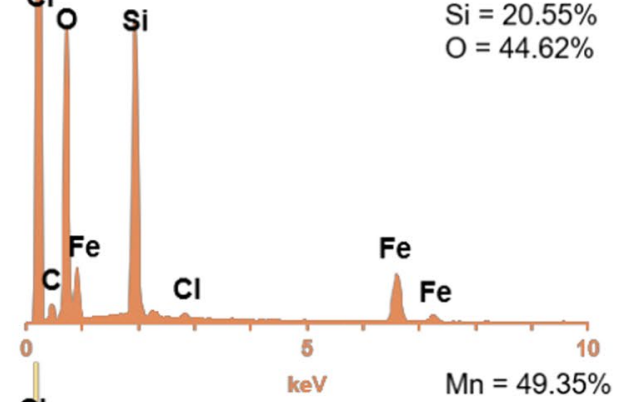

$\mathrm{Cl}$

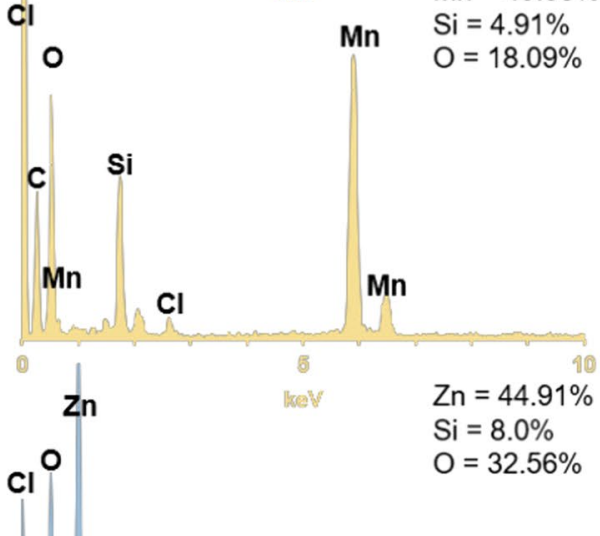

si
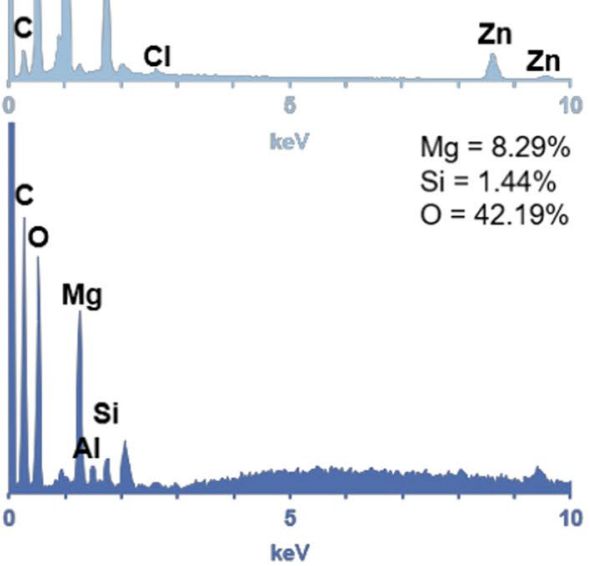
Fig. 3 Backscattered electron micrographs using SEM-EDS of P-laden biochars showing metal-silicate mixtures containing $\mathrm{P}$ in $\mathrm{EB}_{\mathrm{Al}-\mathrm{P}}$ (a), $\mathrm{EB}_{\mathrm{Fe}-\mathrm{P}}$ (b), $\mathrm{EB}_{\mathrm{Mn}-\mathrm{P}}(\mathbf{c}), \mathrm{EB}_{\mathrm{Zn}-\mathrm{P}}(\mathbf{d})$, and $\mathrm{EB}_{\mathrm{Mg-P}}(\mathbf{e})$. Small orange squares represent the area of SEM-EDS analysis. Atomic ratios: $\mathrm{Al}: \mathrm{Si}: \mathrm{P} \approx 1.00: 0.02: 0.01$, $\mathrm{Fe}: \mathrm{Si}: \mathrm{P} \approx 1.00: 3.76: 0.12$,

$\mathrm{Mn}: \mathrm{Si}: \mathrm{P} \approx 1.00: 0.15: 0.76$, $\mathrm{Zn}: \mathrm{Si}: \mathrm{P} \approx 1.00: 0.15: 0.76$, and $\mathrm{Mg}: \mathrm{Si}: \mathrm{P} \approx 1.00: 0.37: 0.39$ a

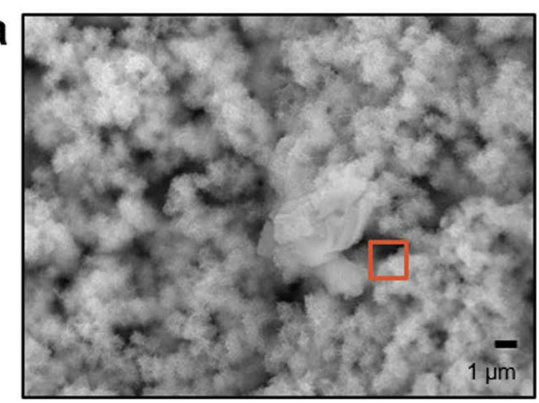

b

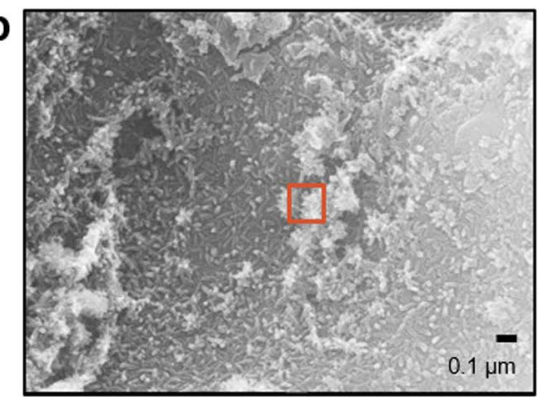

c

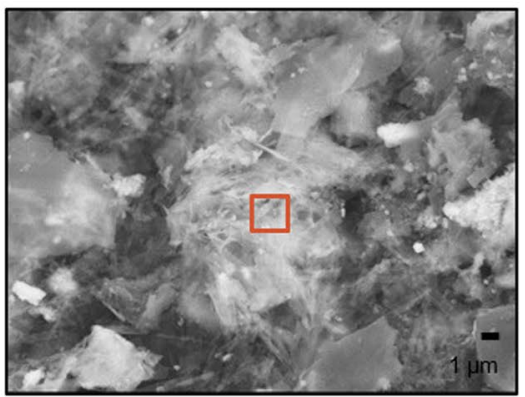

d

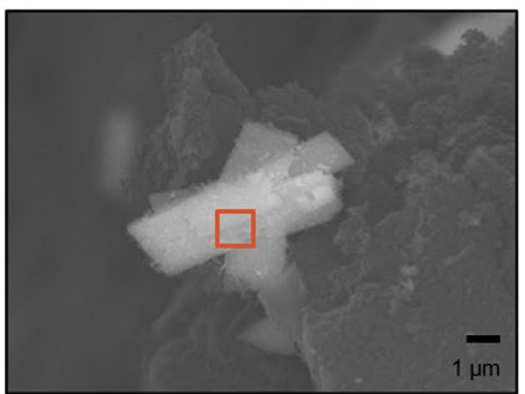

e

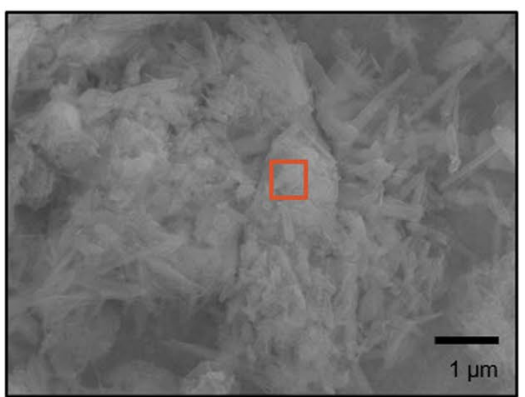

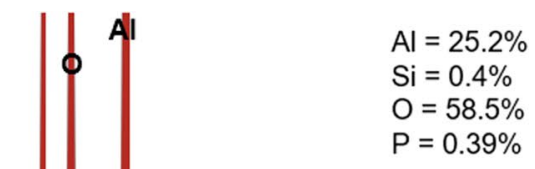

$\mathrm{Fe}$

$\mathrm{Fe}$

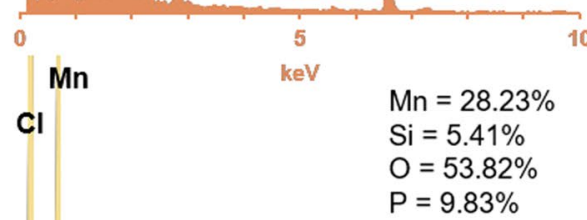

o

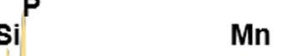

Mn

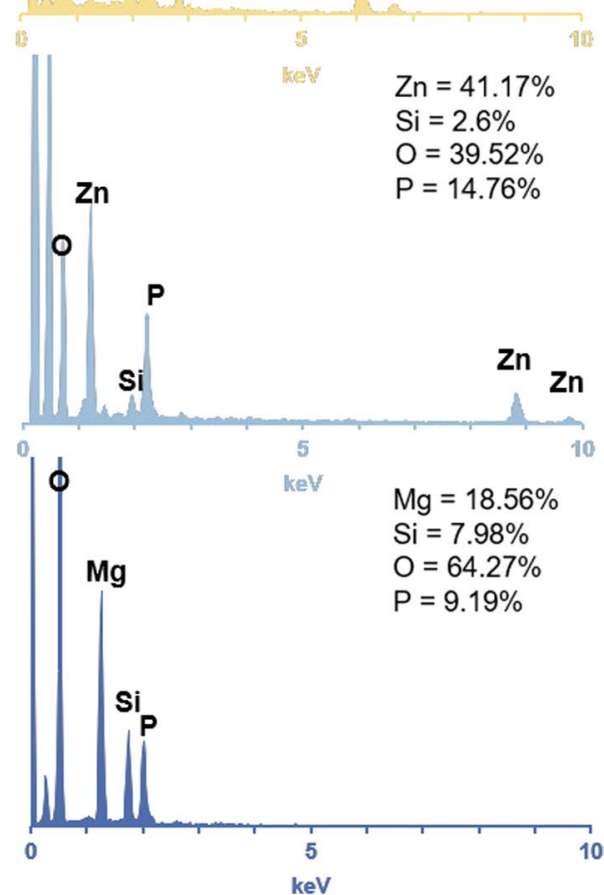




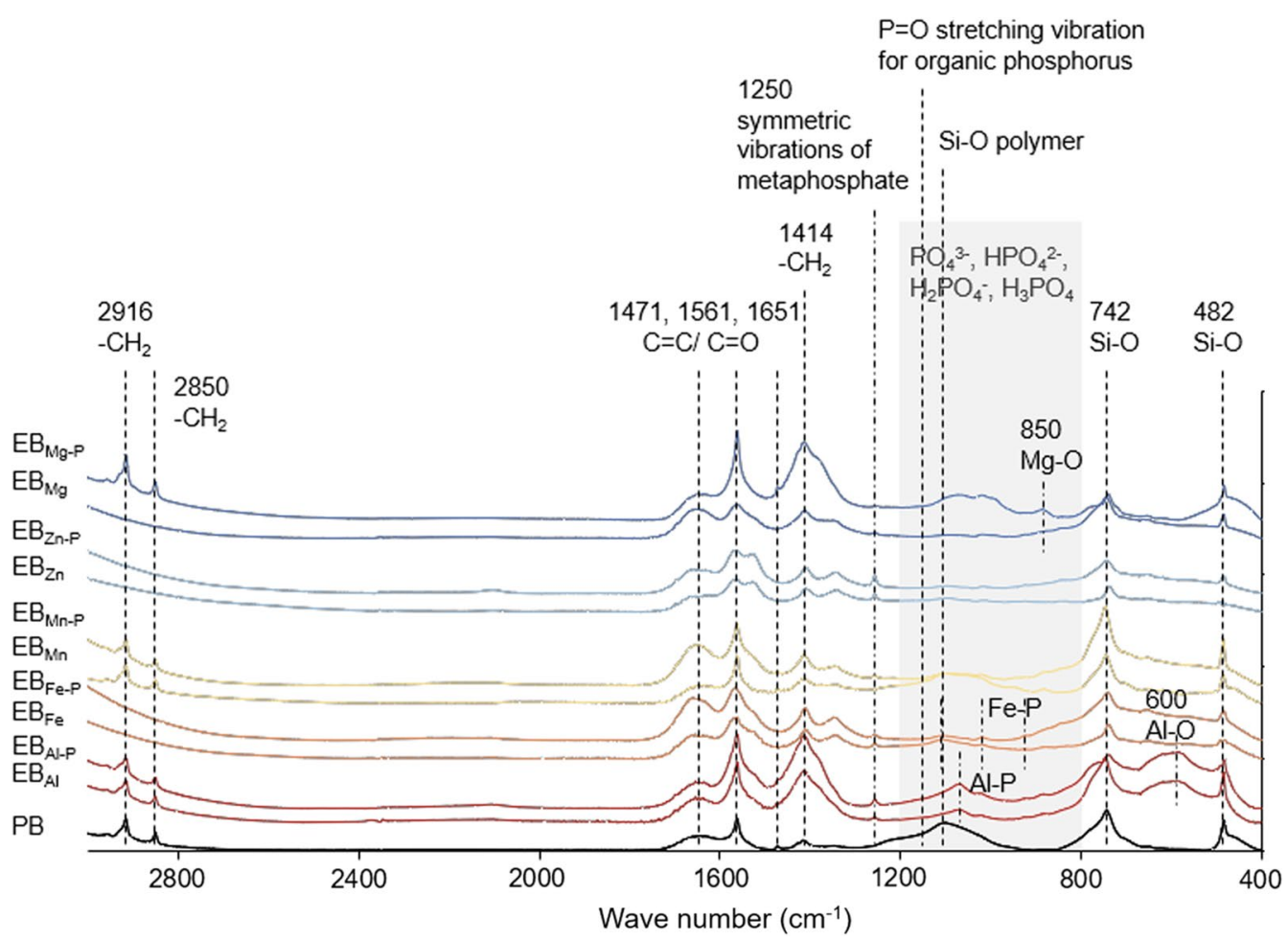

Fig. 4 FTIR spectra and spectroscopic assignment of pristine biochar (PB), mineral-engineered biochars $\left(\mathrm{EB}_{\mathrm{Al}}, \mathrm{EB}_{\mathrm{Fe}}, \mathrm{EB}_{\mathrm{Mn}}, \mathrm{EB}_{\mathrm{Zn}}\right.$, and $\left.\mathrm{EB}_{\mathrm{Mg}}\right)$, and P-laden biochars $\left(\mathrm{EB}_{\mathrm{Al}-\mathrm{P}}, \mathrm{EB}_{\mathrm{Fe}-\mathrm{P}}, \mathrm{EB}_{\mathrm{Mn}-\mathrm{P}}, \mathrm{EB}_{\mathrm{Zn}-\mathrm{P}}\right.$, and $\left.\mathrm{EB}_{\mathrm{Mg}-\mathrm{P}}\right)$

0.01 to $0.53 \mathrm{~L} / \mathrm{mg}$. The lowest $K_{L}$ value in the $\mathrm{EB}_{\mathrm{Mg}}$ sample and the highest value in the $\mathrm{EB}_{\mathrm{Fe}}$ sample suggested low and high P-binding energies for the $\mathrm{EB}_{\mathrm{Mg}}$ and $\mathrm{EB}_{\mathrm{Fe}}$ samples, respectively. The Freundlich $K_{f}$ coefficient (associated with the sorption site quantity) ranged from 0.12 for the $\mathrm{EB}_{\mathrm{Fe}}$ to 12.21 for the $\mathrm{EB}_{\mathrm{Al}}$ samples. The Freundlich $n$ constant, interpreted as differences in the adsorption sites of adsorbents, substantially differed from 0.15 for the $\mathrm{EB}_{\mathrm{Al}}$ to 0.80 for the $\mathrm{EB}_{\mathrm{Fe}}$ samples, with a low value indicating heterogeneity of the reactive adsorption sites and a high value denoting homogeneity of the adsorption sites (Sposito 1980). The $n$ constant value of below unity also demonstrated that the chemical mechanisms were more favorable under the tested conditions for P sorption than the physical processes (Ajmal et al. 2018; Ozcan et al. 2005). This evidence conformed to the data showing that enhancing the specific surface area and the cumulative pore volume of the engineered biochar caused by metal oxide impregnation demoted their maximum P-adsorption capacities (Fig. S2).

\subsubsection{Adsorption kinetics}

The kinetics data demonstrated that $\mathrm{P}$ adsorption onto the EB samples was slow and reached equilibrium after $48 \mathrm{~h}$ (Fig. S3). With the addition of the P contents in the samples at $Q_{m}$ concentrations of $32.3,31.7,38.6,25.6$, and $46.5 \mathrm{mg} / \mathrm{g}$ for the respective $\mathrm{EB}_{\mathrm{Al}}, \mathrm{EB}_{\mathrm{Fe}}, \mathrm{EB}_{\mathrm{Mn}}, \mathrm{EB}_{\mathrm{Zn}}$, and $\mathrm{EB}_{\mathrm{Mg}}$ samples (Table 2), the $\mathrm{EB}_{\mathrm{Mn}}$, and $\mathrm{EB}_{\mathrm{Mg}}$ samples removed 76 and $74 \%$, respectively, of the total added $P$ after $72 \mathrm{~h}$. The $\mathrm{EB}_{\mathrm{Al}}, \mathrm{EB}_{\mathrm{Zn}}$, and $\mathrm{EB}_{\mathrm{Fe}}$ samples removed 62, 55, and $45 \%$, respectively, of the total added $P$.

Five kinetic models (zero-order, first-order, parabolic diffusion, power function, and Elovich model) were used to describe the $\mathrm{P}$-adsorption kinetics on the engineered biochar. The results demonstrated that the Elovich model provided the best description for the $\mathrm{P}$ sorption kinetics

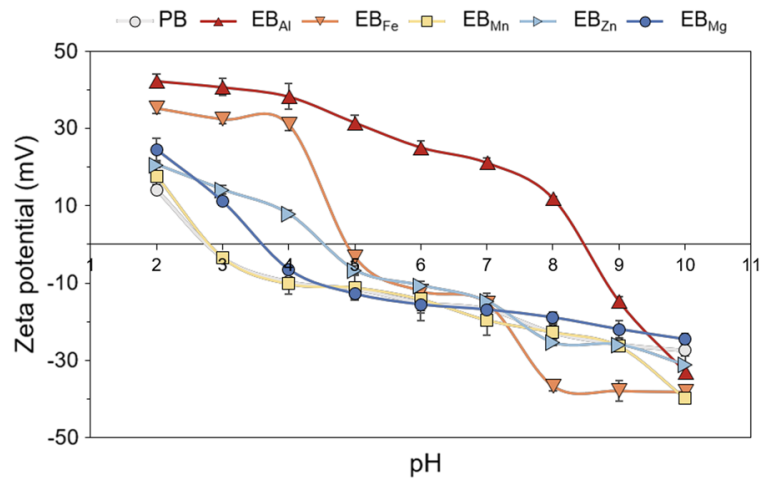

Fig. 5 Zeta potential of $\mathrm{PB}, \mathrm{EB}_{\mathrm{Al}}, \mathrm{EB}_{\mathrm{Fe}}, \mathrm{EB}_{\mathrm{Mn}}, \mathrm{EB}_{\mathrm{Zn}}$, and $\mathrm{EB}_{\mathrm{Mg}}$ samples. Symbols are for experimental data, and error bars show standard error of duplicates 
in most samples with $\mathrm{R}^{2}$ values in the range 0.79-0.99 (mean $=0.92$, Table 3 ), suggesting that the adsorption of $\mathrm{P}$ onto the mineral-engineered biochar could be a diffusioncontrolled mechanism. These data agreed well with Wang et al. (2015) and Zhang and Gao (2013), showing that the $\mathrm{As}(\mathrm{V})$ adsorption kinetics on Mn-engineered biochar and Al-engineered biochar were well fitted by the Elovich model $\left(R^{2}=0.98\right.$ and 0.96 , respectively). This may have been due to the colloidal particles of metal (oxyhydr) oxides in the biochar acting as the primary adsorbents for added P. However, other studies suggested that first- and second-order equations better explained the sorption kinetics data for As (V) onto Fe biochar and P sorption onto Mg-biochar (Yao et al. 2013; Zhang et al. 2013), indicating that multiple mechanisms might control the adsorption of oxyanions onto mineral-engineered biochar. The $\mathrm{R}^{2}$ values for the other models decreased in the following order: power function $\left(R^{2}=0.84-0.99\right.$, mean $\left.=0.90\right)$ and parabolic diffusion $\left(\mathrm{R}^{2}=0.77-0.99\right.$, mean $\left.=0.90\right)>$ zeroorder $\left(\mathrm{R}^{2}=0.66-0.91\right.$, mean $\left.=0.79\right)>$ first-order $\left(R^{2}=0.67-0.75\right.$, mean $\left.=0.65\right)$.

\subsubsection{Adsorption envelope}

From the P sorption of each EB sample at the defined $Q_{m}$ levels and different $\mathrm{pH}$ values of 4.0,6.0, and 8.0, it was evident that the initial $\mathrm{pH}$ values of the $\mathrm{KH}_{2} \mathrm{PO}_{4}$ solution made a substantial contribution to the $\mathrm{P}$-sorption capacity of the engineered biochar. The highest $\mathrm{P}$ adsorption for most samples $\left(\mathrm{EB}_{\mathrm{Al}}, \mathrm{EB}_{\mathrm{Fe}}, \mathrm{EB}_{\mathrm{Zn}}\right.$, and $\left.\mathrm{EB}_{\mathrm{Mg}}\right)$ occurred at solution $\mathrm{pH}$ 4.0, except for the $\mathrm{EB}_{\mathrm{Mn}}$ samples with the highest $\mathrm{P}$ at pH 6.0 (Fig. 7). The P-retention capacities for the EB samples at $\mathrm{pH} 8.0$ decreased substantially by $17-76 \%$ and 24-67\% compared to those at $\mathrm{pH} 4.0$ and 6.0, respectively. This could be due to the initial solution $\mathrm{pH}$ of 4.0 largely deviating from the PZC values of the pure (oxyhydr)oxides of $\mathrm{Al}$ (boehmite: 8.5), $\mathrm{Fe}$ (magnetite and synthetic hematite: 4.8-7.0), Mn (manganese oxide: 4.0-4.5), Zn (zinc oxide: 8.7-9.7), and $\mathrm{Mg}$ (magnesium oxide: 12-13) (Adair et al.
2001; Wood et al. 1990). The strong acidic conditions at pH 4.0 could have promoted the positively charged sites of the metal (oxyhydr)oxides and metal-silicate compounds within the engineered biochar and thus promoted the electrostatic attraction forces between the metal (oxyhydr)oxides and the added aqueous $\mathrm{P}$ (Yao et al. 2011). These results corroborated those acidic conditions more efficient than alkaline conditions for the EB samples in P removal from aqueous solution. Nonetheless, the low IEP values of the $\mathrm{EB}_{\mathrm{Mn}}, \mathrm{EB}_{\mathrm{Mg}}, \mathrm{EB}_{\mathrm{Zn}}$, and $\mathrm{EB}_{\mathrm{Fe}}$ biochar samples suggested that the electrostatic attraction between metal oxides in biochar particles and $\mathrm{P}$ was unlikely to be the primary retention mechanism for $\mathrm{P}$ in the current study. However, chemisorption as revealed by the Freundlich $n$ constant (Table 2) and coprecipitation as shown by SEM analysis (Figs. 2,3) did control aqueous-P reclamation under the studied conditions.

\subsection{Regeneration and extractability study of phosphorus-laden biochar}

The absolute and relative amounts of $\mathrm{P}$ extracted using a citric acid solution are given in Fig. 8. The results showed that the $\mathrm{EB}_{\mathrm{Mg}-\mathrm{P}}$ sample had the highest value of citric acid extractable $P(2.23 \mathrm{mg} / \mathrm{g})$, followed by the $\mathrm{EB}_{\mathrm{Zn}-\mathrm{P}}$ $(1.65 \mathrm{mg} / \mathrm{g}), \mathrm{EB}_{\mathrm{Mn}-\mathrm{P}}(1.24 \mathrm{mg} / \mathrm{g}), \mathrm{EB}_{\mathrm{Fe}-\mathrm{P}}(0.45 \mathrm{mg} / \mathrm{g})$, and $\mathrm{EB}_{\mathrm{Al}-\mathrm{P}}$ samples $(0.0017 \mathrm{mg} / \mathrm{g})$, respectively. Considering the relative amounts of extracted $\mathrm{P}$, the $\mathrm{EB}_{\mathrm{Zn}-\mathrm{P}}$ samples provided the highest $\mathrm{P}$ release of $69 \%$ of the total $\mathrm{P}$ and the other extracted $\mathrm{P}$ values decreased in the following order: $\mathrm{EB}_{\mathrm{Mg}-\mathrm{P}}(65 \%)>\mathrm{EB}_{\mathrm{Mn}-\mathrm{P}}(35 \%)>\mathrm{EB}_{\mathrm{Fe}-\mathrm{P}}(19 \%)>\mathrm{EB}_{\mathrm{Al}-\mathrm{P}}$ $(0.044 \%)$. This demonstrated that $\mathrm{EB}_{\mathrm{Mg}-\mathrm{P}}$ remained the best material for both P-adsorbent capacity and P-recycled fertilizer. Furthermore, the results suggested a new potential application of $\mathrm{EB}_{\mathrm{Zn}-\mathrm{P}}, \mathrm{EB}_{\mathrm{Mn}-\mathrm{P}}$, and $\mathrm{EB}_{\mathrm{Fe}-\mathrm{P}}$ as P-recycled fertilizers. However, the $\mathrm{EB}_{\mathrm{Al}-\mathrm{P}}$ samples had a very low value of citric acid extractable $\mathrm{P}$, reflecting its poor potential use as a P fertilizer.

Furthermore, the concurrent release of the host metals from each engineered biochar through the citric extraction
Table 2 Coefficients and correlation coefficients of Langmuir and Freundlich models for $\mathrm{P}$ adsorption onto Al-, Fe, Mn-, Zn-, and $\mathrm{Mg}$-engineered biochars produced from rice husk treated with $\mathrm{Al}, \mathrm{Fe}, \mathrm{Mn}, \mathrm{Zn}$, and $\mathrm{Mg}$ $\left(\mathrm{EB}_{\mathrm{Al}}, \mathrm{EB}_{\mathrm{Fe}}, \mathrm{EB}_{\mathrm{Mn}}, \mathrm{EB}_{\mathrm{Zn}}\right.$, and $\mathrm{EB}_{\mathrm{Mg}}$ )

\begin{tabular}{|c|c|c|c|c|c|c|}
\hline \multirow[b]{2}{*}{ Sample } & \multicolumn{3}{|c|}{ Langmuir } & \multicolumn{3}{|l|}{ Freundlich } \\
\hline & $\begin{array}{l}Q_{m} \\
(\mathrm{mg} / \mathrm{g})\end{array}$ & $\begin{array}{l}K_{L} \\
(\mathrm{~L} / \mathrm{mg})\end{array}$ & $\mathrm{R}^{2}$ & $\begin{array}{l}K_{f} \\
\left(\mathrm{mg}^{1-\mathrm{n}} \mathrm{L}^{\mathrm{n}} / \mathrm{g}\right)\end{array}$ & $n$ & $\mathrm{R}^{2}$ \\
\hline PB & 42.3 & 0.001 & 0.91 & 0.01 & 1.34 & 0.94 \\
\hline $\mathrm{EB}_{\mathrm{Al}}$ & 32.3 & 0.02 & 0.99 & 12.21 & 0.15 & 0.91 \\
\hline $\mathrm{EB}_{\mathrm{Fe}}$ & 31.7 & 0.53 & 0.72 & 0.12 & 0.80 & 0.96 \\
\hline $\mathrm{EB}_{\mathrm{Mn}}$ & 38.6 & 0.04 & 0.99 & 2.85 & 0.43 & 0.96 \\
\hline $\mathrm{EB}_{\mathrm{Zn}}$ & 25.6 & 0.29 & 0.86 & 0.74 & 0.52 & 0.97 \\
\hline $\mathrm{EB}_{\mathrm{Mg}}$ & 46.5 & 0.01 & 0.98 & 5.89 & 0.37 & 0.65 \\
\hline
\end{tabular}



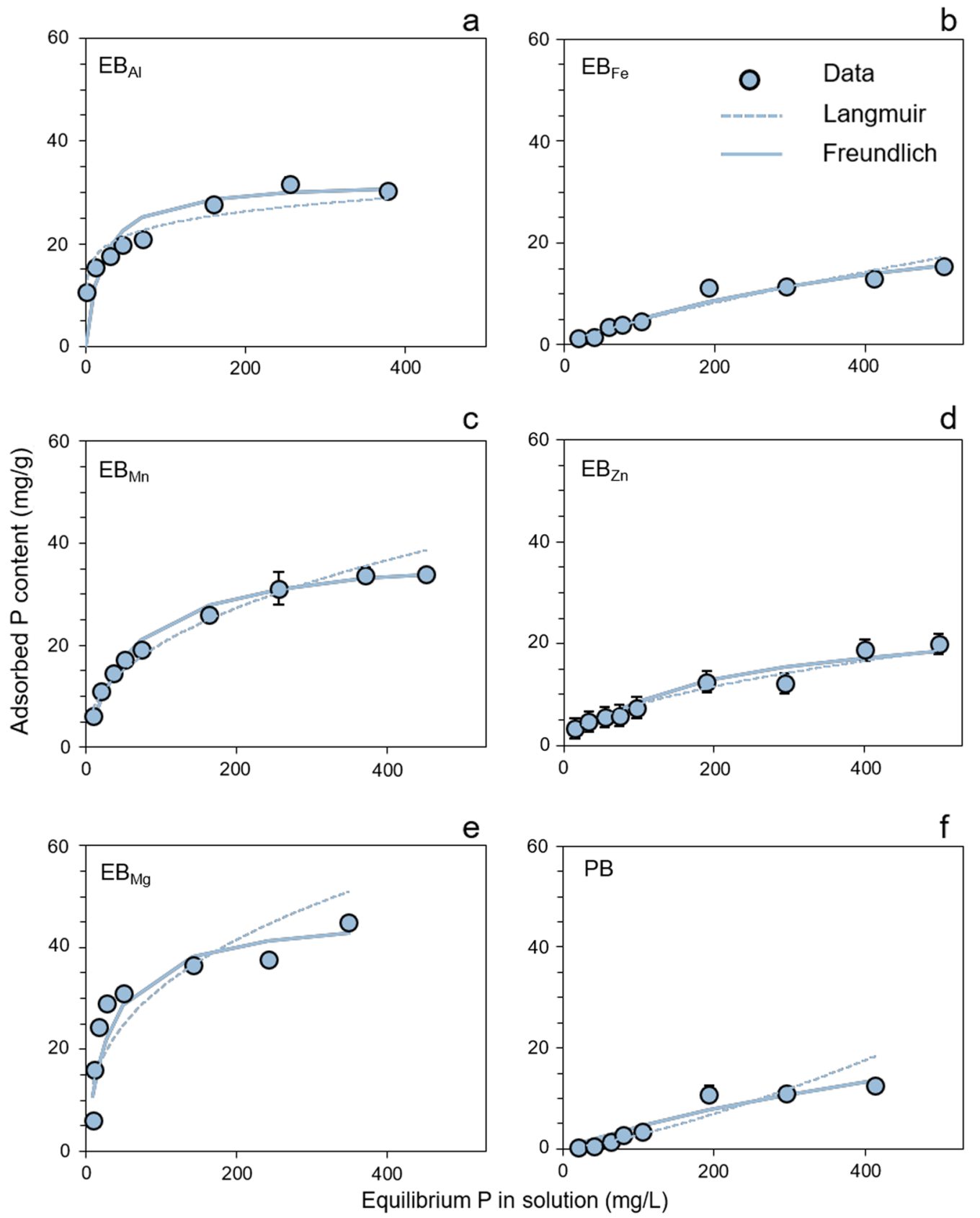

Fig. 6 Phosphorus adsorption isotherms of engineered biochars produced from rice husk treated with $\mathrm{Al}\left(\mathrm{EB}_{\mathrm{Al}}\right), \mathrm{Fe}\left(\mathrm{EB}_{\mathrm{Fe}}\right), \mathrm{Mn}\left(\mathrm{EB}_{\mathrm{Mn}}\right)$, $\mathrm{Zn}\left(\mathrm{EB}_{\mathrm{Zn}}\right)$, and $\mathrm{Mg}\left(\mathrm{EB}_{\mathrm{Mg}}\right)(\mathbf{a}-\mathbf{e}$, respectively) compared to pristine

(55.34 mg Mg /g from $\mathrm{EB}_{\mathrm{Mg}-\mathrm{P}}, 49.88 \mathrm{mg} \mathrm{Zn} / \mathrm{g}$ from $\mathrm{EB}_{\mathrm{Zn}-\mathrm{P}}$, $25.64 \mathrm{mg} \mathrm{Mn} / \mathrm{g}$ from $\mathrm{EB}_{\mathrm{Mn}-\mathrm{P}}$, and $1.56 \mathrm{mg} \mathrm{Fe} / \mathrm{g} \mathrm{EB}_{\mathrm{Fe}-\mathrm{P}}$ ) corresponded to $46.80,47.47,34.14$, and $0.53 \%$, respectively, of the total host metal concentrations. This suggested a potential use of the $\mathrm{Mg}$-, $\mathrm{Zn}$-, and $\mathrm{Mn}$-biochars for releasing the host metals as plant nutrients, in addition to the $\mathrm{P}$ release. However, strong $\mathrm{P}$ binding to Fe oxides in the $\mathrm{Fe}$-biochar remained to limit the Fe release and availability. biochar $(\mathrm{PB}, \mathbf{f})$. Symbols are for experimental data, and error bars show the standard error of triplicates

\subsection{Metal-silicate biochar as a possible new recycled fertilizer of phosphate and micronutrients}

Many studies on engineered biochar from different biomass materials with $\mathrm{Al}, \mathrm{Fe}, \mathrm{Mn}$, or $\mathrm{Mg}$ showed that metal (oxyhydr)oxides were the main components in the designed biochar, including boehmite in Al-biochar 
Table 3 Coefficients of kinetics models for $\mathrm{P}$ adsorption onto Al-, Fe, $\mathrm{Mn}-, \mathrm{Zn}$-, and $\mathrm{Mg}$-engineered biochars from rice husk treated with $\mathrm{Al}, \mathrm{Fe}, \mathrm{Mn}, \mathrm{Zn}$, and $\mathrm{Mg}\left(\mathrm{EB}_{\mathrm{Al}}, \mathrm{EB}_{\mathrm{Fe}}, \mathrm{EB}_{\mathrm{Mn}}, \mathrm{EB}_{\mathrm{Zn}}\right.$, and $\left.\mathrm{EB}_{\mathrm{Mg}}\right)$

\begin{tabular}{|c|c|c|c|c|}
\hline Sample & Kinetic model & Parameter $1^{\mathrm{a}}$ & Parameter $2^{\mathrm{a}}$ & $\mathrm{R}^{2}$ \\
\hline \multirow[t]{5}{*}{$\mathrm{EB}_{\mathrm{Al}}$} & Zero order & $k=0.12$ & $q_{0}=15.3$ & 0.66 \\
\hline & First order & $k=0.0063$ & $q_{0}=15.3$ & 0.67 \\
\hline & Parabolic diffusion & $a=1.2$ & $b=13.2$ & 0.77 \\
\hline & Power function & $a=0.12$ & $b=13.4$ & 0.84 \\
\hline & Elovich model & $a=5.03$ & $b=13.0$ & 0.79 \\
\hline \multirow[t]{5}{*}{$\mathrm{EB}_{\mathrm{Fe}}$} & Zero order & $k=0.10$ & $q_{0}=8.9$ & 0.81 \\
\hline & First order & $k=0.0089$ & $q_{0}=8.3$ & 0.74 \\
\hline & Parabolic diffusion & $a=1.0$ & $b=7.1$ & 0.92 \\
\hline & Power function & $a=0.17$ & $b=7.4$ & 0.90 \\
\hline & Elovich model & $a=4.2$ & $b=7.0$ & 0.92 \\
\hline \multirow[t]{5}{*}{$\mathrm{EB}_{\mathrm{Mn}}$} & Zero order & $k=0.30$ & $q_{0}=6.9$ & 0.91 \\
\hline & First order & $k=0.022$ & $q_{0}=5.9$ & 0.75 \\
\hline & Parabolic diffusion & $a=3.0$ & $b=1.8$ & 0.99 \\
\hline & Power function & $a=0.44$ & $b=4.1$ & 0.99 \\
\hline & Elovich model & $a=12.0$ & $b=1.7$ & 0.96 \\
\hline \multirow[t]{5}{*}{$\mathrm{EB}_{\mathrm{Zn}}$} & Zero order & $k=0.16$ & $q_{0}=4.9$ & 0.78 \\
\hline & First order & $k=0.023$ & $q_{0}=2.6$ & 0.49 \\
\hline & Parabolic diffusion & $a=1.7$ & $b=1.9$ & 0.91 \\
\hline & Power function & $a=0.51$ & $b=2.1$ & 0.86 \\
\hline & Elovich model & $a=7.3$ & $b=1.4$ & 0.99 \\
\hline \multirow[t]{5}{*}{$\mathrm{EB}_{\mathrm{Mg}}$} & Zero order & $k=0.55$ & $q_{0}=4.4$ & 0.79 \\
\hline & First order & $k=0.049$ & $q_{0}=0.77$ & 0.59 \\
\hline & Parabolic diffusion & $a=5.6$ & $b=-5.6$ & 0.91 \\
\hline & Power function & - & - & - \\
\hline & Elovich model & $a=23.5$ & $b=-6.6$ & 0.94 \\
\hline
\end{tabular}

${ }^{\mathrm{a} C o e f f i c i e n t s ~ i n ~ k i n e t i c ~ e q u a t i o n s: ~ z e r o-o r d e r ~ e q u a t i o n ~}\left(q_{\mathrm{t}}=-k t+q_{0}\right)$, first-order equation (ln $q_{\mathrm{t}}=-k t+\ln q_{0}$ ), parabolic diffusion $\left(q_{\mathrm{t}}=a t^{0.5}+b\right)$, power function $\left(q_{\mathrm{t}}=b t^{a}\right)$, and Elovich model $\left(q_{\mathrm{t}}=a\right.$ $\log t+b)$
(Zhang and Gao 2013), maghemite in cottonwood Febiochar (Zhang et al. 2013), manganosite in loblolly pine Mn-biochar (Wang et al. 2015), brucite in tomato leaf Mgbiochar (Yao et al. 2013) and periclase in Mg-biochar from several agricultural wastes namely tomato leaves, sugar beet tailings, sugarcane bagasse, cottonwood, pinewood, and peanut shells (Yao et al. 2013; Zhang et al. 2012). Our data obtained using the XRD and SEM-EDS techniques for engineered biochar rice husk provided new insight into the role of silicate minerals in the biomass as contributing substantially to the formation of the metal-silicate compounds in the engineered biochar (Figs. 2, 3), which could act as the primary host for $\mathrm{P}$ in the studied mineralengineered biochar samples. The large variations in the compounds, which were newly formed in the mineralengineered biochar, strongly controlled their P-sorption capacity and their potential use as P-recycled fertilizers.

All the engineered biochar samples could be used as effective adsorbents for P removal from aqueous solutions with different levels of efficiency and sorption kinetics, suggesting that varying the solid-to-solution ratios should be considered for each engineered biochar to achieve its maximum P-removal effectiveness. Considering the P-sorption maximum capacities, the $\mathrm{EB}_{\mathrm{Al}}$ and $\mathrm{EB}_{\mathrm{Mg}}$ samples (38.6 and $46.5 \mathrm{mg} / \mathrm{g}$, respectively) retained lower $P$ contents than Al-biochar and $\mathrm{Mg}$-biochar in other studies prepared at the same temperature $\left(600{ }^{\circ} \mathrm{C}\right)$, but with different initial biomass, including cottonwood, sugar beet tailings, tree leaves, and tomato leaves that retained P up to $835 \mathrm{mg} / \mathrm{g}$ (Zhang et al. 2012), $135 \mathrm{mg} / \mathrm{g}$ (Zhang and Gao 2013), $122 \mathrm{mg} / \mathrm{g}$ (Luo et al. 2021), and $100 \mathrm{mg} / \mathrm{g}$ (Yao et al. 2013), respectively. The P-retention capacity of the present Fe-biochar (31.7 mg/g) was comparable to the Fe(III) biochar from

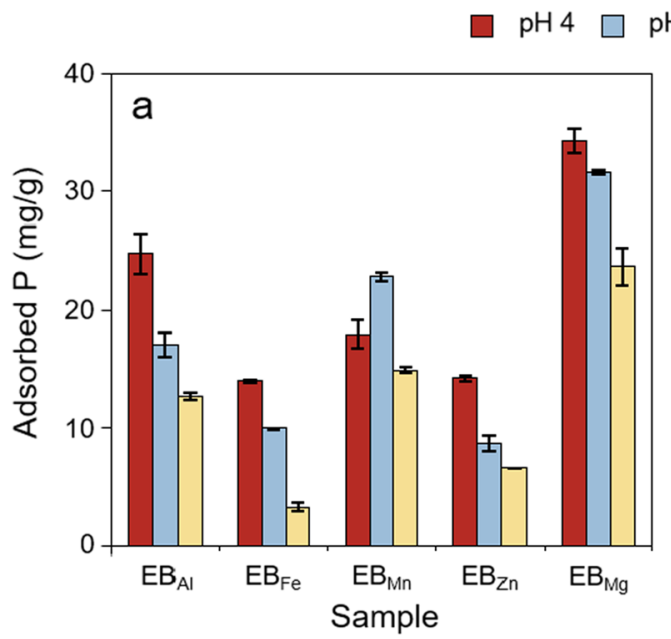

Fig. 7 Absolute (a) and relative percentage (b) of $\mathrm{P}$ adsorption concentration of engineered biochars derived from rice husk treated with $\mathrm{Al}, \mathrm{Fe}, \mathrm{Mn}, \mathrm{Zn}$, and $\mathrm{Mg}\left(\mathrm{EB}_{\mathrm{Al}}, \mathrm{EB}_{\mathrm{Fe}}, \mathrm{EB}_{\mathrm{Mn}}, \mathrm{EB}_{\mathrm{Zn}}\right.$, and $\left.\mathrm{EB}_{\mathrm{Mg}}\right)$ at $\mathrm{pH}$

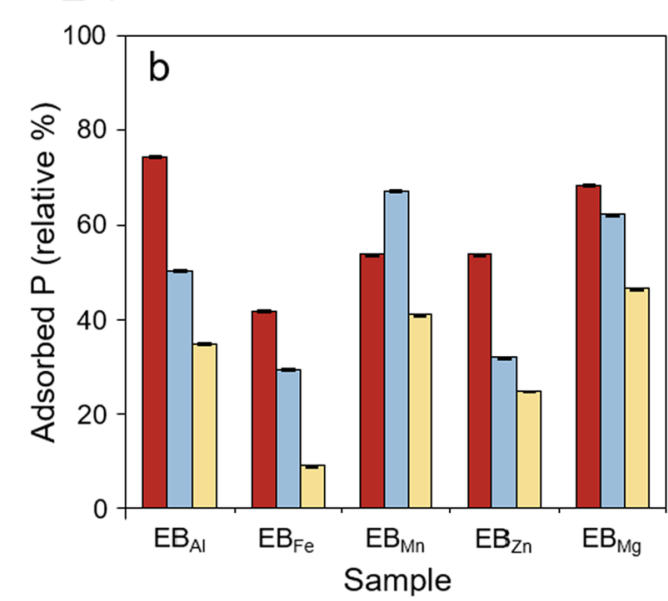

solution values of 4,6 , and 8 . Bar graphs indicate mean values of experimental data with error bars showing standard error 
a

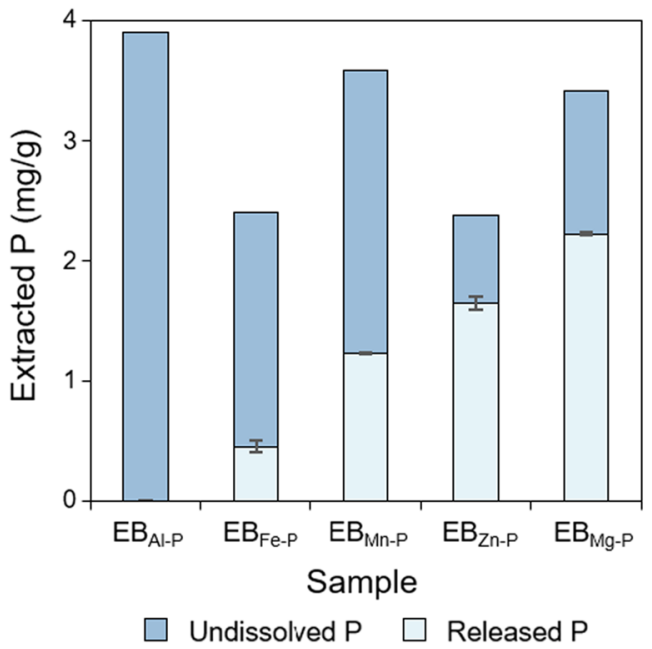

Fig. 8 Absolute (a) and relative (b) concentrations of total and citric acid extractable $\mathrm{P}$ of $\mathrm{P}$-laden biochars derived from rice husk treated with $\mathrm{Al}, \mathrm{Fe}, \mathrm{Mn}, \mathrm{Zn}$, and $\mathrm{Mg}\left(\mathrm{EB}_{\mathrm{Al}-\mathrm{P}}, \mathrm{EB}_{\mathrm{Fe}-\mathrm{P}}, \mathrm{EB}_{\mathrm{Mn}-\mathrm{P}}, \mathrm{EB}_{\mathrm{Zn}-\mathrm{P}}\right.$, and

rice straw of $32.6 \mathrm{mg} / \mathrm{g}$ (Wu et al. 2020). No evidence has been found regarding the P-sorption abilities of $\mathrm{Mn}$ - and Zn-biochars. The current study showed that $\mathrm{EB}_{\mathrm{Fe}}$ and $\mathrm{EB}_{\mathrm{Mn}}$ retained $\mathrm{P}$ at levels as high as $\mathrm{EB}_{\mathrm{Al}}$, but $\mathrm{EB}_{\mathrm{Zn}}$ removed the lowest $P$ amount of $25 \mathrm{mg} / \mathrm{g}$. The main difference between the $\mathrm{P}$ retention capacities in the current study and those of other studies could be mainly attributable to the different chemical compositions of the raw biomass and the designed metals, which could have resulted in the substantial variations in the sizes and shapes of the metal-silicate precipitates in the biochar structures (Figs. 2, 3). Compared to other adsorbents such as montmorillonite-biochar and $\mathrm{Zn} / \mathrm{Al}$ LDH-biochar composites, the mineral-engineered biochars in the current study (25.6-46.5) showed 2-5 times less $\mathrm{P}$ adsorption capacity than other adsorbents such as montmorillonite-biochar and $\mathrm{Zn} / \mathrm{Al}$-LDH-biochar composites with P retention of about $150 \mathrm{mg} / \mathrm{g}$ (Chen et al. 2017; Yang et al. 2019a).

Furthermore, the metal-silicate mixtures observed in the SEM investigation were important host phases for $\mathrm{P}$ in the biochar produced from Si-rich rice husk. The dissolved silicates from the Si-rich material could be coated onto the reactive surfaces of the metal (oxyhydr)oxides or coprecipitated with the host metals and thereby could shift the IEP of the metal (oxyhydr)oxides downward and close to the IEP for quartz (Fig. 5) (Essington 2015). This process resulted in low magnitudes of positive charge sites in the designed metal (oxyhydr)oxides for $\mathrm{P}$ and other oxyanion retention (Hiemstra et al. 2007; Schwertmann and Fechter 1982). In addition, a study on the competitive effect of

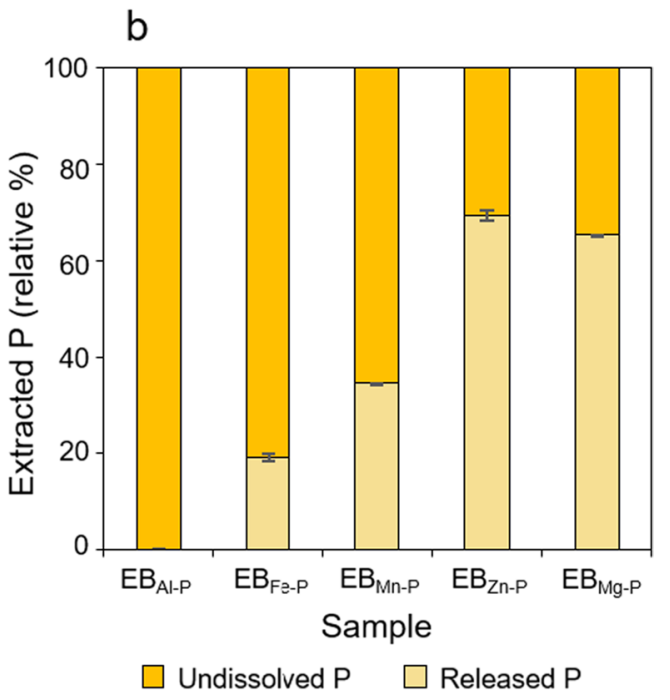

$\mathrm{EB}_{\mathrm{Mg-P}}$, respectively). Bar graphs are mean values of the experimental data with error bars of standard errors from triplicate measurements

silicates on arsenite (As(III)) and arsenate $(\mathrm{As}(\mathrm{V}))$ retention on the hematite surface showed that a higher degree of Si polymerization onto the hematite induced by the longer residence time lowered As(III) and As(V) adsorption on hematite (Christl et al. 2012). The more pronounced effect on the PZC of the metal (oxyhydr)oxides could prevail if the dissolved silicates were coprecipitated with metal (oxyhydr)oxides (Schwertmann and Fechter 1982). This coprecipitation mechanism was likely to be the primary mechanism in the transformation in the surface charge behavior and anionic binding capacity of the metal (oxyhydr)oxides in the current study because the particles of the metal-silicate mixtures under SEM examination typically occurred as discrete particles rather than as Si coated onto the metal (oxyhydr)oxides. The low IEP values of the $\mathrm{Fe}-, \mathrm{Mn}-, \mathrm{Zn}$-, and $\mathrm{Mg}$-engineered biochars were consistent with the metal silicate formation (Figs. 2, 3), presumably through coprecipitation mechanisms. The EDS analysis of the mineral grains under the SEM investigation also revealed the higher Si content in the mineral grains and the lower host metal content (Fig. 9a). Moreover, the more elevated the Si content, the lower the P content in the mineral grains (Fig. 9b). These data confirmed that silicate in the biomass could react with the added host metals and form metal-silicate precipitates that lowered the available sites for $\mathrm{P}$ sorption and retarded its sorption kinetics. Therefore, the roles of silicates importantly affected both the retention and release of anions by the metal (oxyhydr)oxides. 
Most P-laden biochar samples (except for the $\mathrm{EB}_{\mathrm{Al}^{-} \mathrm{P}}$ Samples) released considerable amounts of $\mathrm{P}$ and host metals (Fe, $\mathrm{Mn}, \mathrm{Zn}$, and $\mathrm{Mg}$ ) when extracted using $2 \%$ citric acid (Fig. 8, Table S2). The $\mathrm{EB}_{\mathrm{Zn}-\mathrm{P}}$ samples released the highest $\mathrm{P}$ concentration (69\%), followed by the $\mathrm{EB}_{\mathrm{Mg}-\mathrm{P}}(65 \%), \mathrm{EB}_{\mathrm{Mn}-\mathrm{P}}$ $(35 \%)$, and $\mathrm{EB}_{\mathrm{Fe}-\mathrm{P}}(19 \%)$ samples. Notably, other studies reported that only $4.4 \%$ of the total P $(10.5 \mathrm{mg} / \mathrm{g}$ from $239 \mathrm{mg} / \mathrm{g}$ ) could be extracted using citric acid from corn Mg-biochar (Fang et al. 2014), 14\% of the total P (8.9 mg/g from $65 \mathrm{mg} / \mathrm{g}$ ) extracted by $\mathrm{KCl}$ from oak wood $\mathrm{Mg}$-biochar (Takaya et al. 2016), and $7.6 \%$ of the total P $(7.6 \mathrm{mg} / \mathrm{g}$ from $100 \mathrm{mg} / \mathrm{g}$ ) extracted by Mehlich-3 from tomato leaf $\mathrm{Mg}$ biochar (Yao et al. 2013). The higher extractable P content from the P-laden biochar in the current study than in other studies could be attributed to the metal-silicate precipitates that could have weakened the binding energy for $\mathrm{P}$ on the designed metal oxides. The metal-silicate precipitates enhanced the $\mathrm{P}$ extractability from $\mathrm{EB}_{\mathrm{Zn}}, \mathrm{EB}_{\mathrm{Mn}}$, and $\mathrm{EB}_{\mathrm{Fe}}$ that are strong adsorbents for P. More importantly, other studies reported that 20-30\% (Hedley et al. 1988) or 10-43\% (Santos et al. 2019) of the total P dissolved from rock phosphate was extracted using $2 \%$ citric acid and provided an excellent indication of the high reactivity of rock phosphates (Hedley et al. 1988; Santos et al. 2019).

Although the $\mathrm{EB}_{\mathrm{Al}^{-} \mathrm{P}}$ sample released the lowest $\mathrm{P}$ concentration $(0.044 \%$ of the total $\mathrm{P})$, a recent study on a sand$\mathrm{EB}_{\mathrm{Al}-\mathrm{P}}$ mixture revealed a sufficient amount of Olsen extractable P (11-12 mg/kg) constantly released from the mixture throughout 45 days of incubation (Sornhiran et al. 2021). This result suggested the possible use of Al-biochar as both $\mathrm{P}$-recycled fertilizer in sandy soils with a low $\mathrm{P}$ availability and a high risk of $P$ loss.

The current results highlighted the potential of mineral-engineered biochar with abundant $\mathrm{Si}$ as both adsorbents for $\mathrm{P}$ removal and subsequent reuse as P-recycled fertilizers. Furthermore, the release of the host metals ( $\mathrm{Mg}, \mathrm{Zn}$, and $\mathrm{Mn}$ ) from each engineered biochar through extraction suggested the additional advantage of the mineral-engineered biochar in the current study for supplying secondary ( $\mathrm{Mg}$ ) and micronutrient ( $\mathrm{Zn}$ and $\mathrm{Mn}$ ) fertilizers in addition to the recycled P. However, further studies should examine the kinetics and suitable chemical conditions for releasing $\mathrm{P}$ and micronutrients from the mineral-engineered biochar.

\section{Conclusions}

This work investigated the retrieval and reuse of $\mathrm{P}$ from aqueous solution using mineral-engineered biochars. Silicon-rich rice husk was used as the raw material for the novel design of Al-, Fe-, Mn-, Zn-, and Mg-(oxyhydr)oxide-biochar composites. The silicate compounds in the raw biomass induced the formation of metal-silicate compounds in the biochar framework and acted as the main absorbents for P. All mineral-engineered biochars caused slow sorption kinetics but offered reasonable sorption ability to $\mathrm{P}$ in the aqueous solution because the metal-silicate compounds had lower chemically reactive surfaces for $\mathrm{P}$ than the pure metal (oxyhydr)oxides typically found in diverse engineered biochars from other materials with less silicon content. The silicate compounds could weaken the P-binding capacity through adsorption onto or coprecipitation with metal (oxyhydr)oxides in the engineered biochar. Therefore, the silicate compounds showed the greater significance and novelty of the metal-silicate biochars as P-recycled fertilizer than the mineral-engineered biochar in other studies where strong binding capacity makes it difficult to release $\mathrm{P}$ for plant utilization.
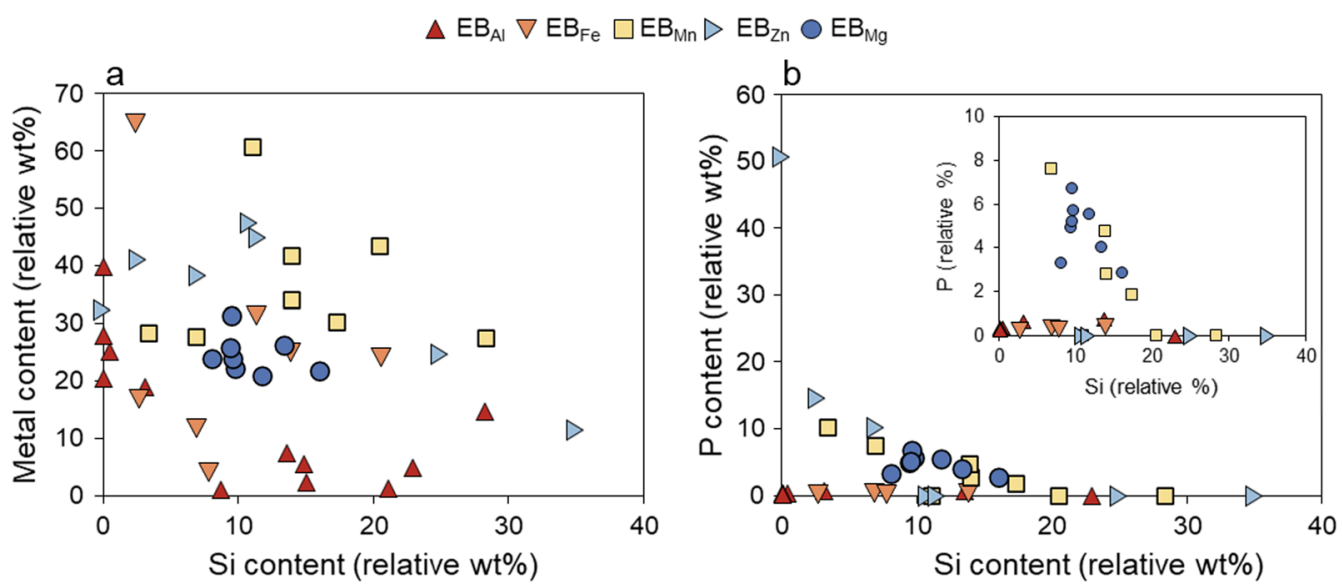

Fig. 9 Bivariate plots of Si content with host metal (a) and P (b) contents of mineral grains within mineral-engineered biochars based on SEMEDS investigation 
Supplementary Information The online version contains supplementary material available at https://doi.org/10.1007/s42773-021-00129-8.

Acknowledgements This work was financially supported by the Kasetsart University Research and Development Institute (KURDI), Bangkok, Thailand under Grant No. 40.60 and partly supported by the National Nanotechnology Center (NANOTEC), NSTDA, Ministry of Science and Technology, Thailand, through its program of Research Network NANOTEC (RNN).

Authors' contributions NS: writing-original draft, formal analysis, investigation, visualization. SA: writing-reviewing and editing. NP: writing-reviewing and editing, investigation. WW: conceptualization, methodology, formal analysis, resources, writing - review and editing, visualization, supervision, funding acquisition.

Funding This work was funded by Kasetsart University Research and Development Institute (KURDI), Bangkok, Thailand under Grant No. 40.60, and partly supported by the National Nanotechnology Center (NANOTEC), NSTDA, Ministry of Science and Technology, Thailand, through its program of Research Network NANOTEC (RNN).

Availability of data and materials All data generated or analyzed during this study are included in this published article and its supplementary information files.

\section{Declarations}

Competing interests The authors have no conflicts of interest to declare that are relevant to the content of this article.

Open Access This article is licensed under a Creative Commons Attribution 4.0 International License, which permits use, sharing, adaptation, distribution and reproduction in any medium or format, as long as you give appropriate credit to the original author(s) and the source, provide a link to the Creative Commons licence, and indicate if changes were made. The images or other third party material in this article are included in the article's Creative Commons licence, unless indicated otherwise in a credit line to the material. If material is not included in the article's Creative Commons licence and your intended use is not permitted by statutory regulation or exceeds the permitted use, you will need to obtain permission directly from the copyright holder. To view a copy of this licence, visit http://creativecommons.org/licenses/by/4.0/.

\section{References}

Adair JH, Suvaci E, Sindel J (2001) Surface and colloid chemistry. In: Buschow KHJ, Cahn RW, Flemings MC, Ilschner B, Kramer EJ, Mahajan S, Veyssière P (eds) Encyclopedia of materials: science and technology. Elsevier, Oxford

Ahmad M, Rajapaksha AU, Lim JE, Zhang M, Bolan N, Mohan D, Vithanage M, Lee SS, Ok YS (2014) Biochar as a sorbent for contaminant management in soil and water: a review. Chemosphere 99:19-33. https://doi.org/10.1016/j.chemosphere.2013.10.071

Ajmal Z, Muhmood A, Usman M, Kizito S, Lu J, Dong R, Wu S (2018) Phosphate removal from aqueous solution using iron oxides: Adsorption, desorption and regeneration characteristics. J Colloid Interface Sci 528:145-155. https://doi.org/10.1016/j. jcis.2018.05.084
Akgul G, Maden TB, Diaz E, Jimenez EM (2019) Modification of tea biochar with $\mathrm{Mg}, \mathrm{Fe}, \mathrm{Mn}$ and $\mathrm{Al}$ salts for efficient sorption of $\mathrm{PO}_{4}{ }^{3-}$ and $\mathrm{Cd}^{2+}$ from aqueous solutions. J Water Reuse Desal 9:57-66. https://doi.org/10.2166/wrd.2018.018

Arai Y, Sparks DL (2001) ATR-FTIR spectroscopic investigation on phosphate adsorption mechanisms at the ferrihydrite-water interface. J Colloid Interface Sci 241:317-326. https://doi.org/ $10.1006 /$ jcis.2001.7773

Bais HP, Weir TL, Perry LG, Gilroy S, Vivanco JM (2006) The role of root exudates in rhizosphere interactions with plants and other organisms. Annu Rev Plant Biol 57:233-266. https://doi. org/10.1146/annurev.arplant.57.032905.105159

Chen M, Ma LQ (2001) Comparison of three aqua regia digestion methods for twenty Florida soils. Soil Sci Soc Am J 65:491499. https://doi.org/10.2136/sssaj2001.652491x

Chen L, Chen XL, Zhou CH, Yang HM, Ji SF, Tong DS, Zhong ZK, Yu WH, Chu MQ (2017) Environmental-friendly montmorillonite-biochar composites: facile production and tunable adsorption-release of ammonium and phosphate. J Clean Prod 156:648-659. https://doi.org/10.1016/j.jclepro.2017.04.050

Christl I, Brechbühl Y, Graf M, Kretzschmar R (2012) Polymerization of silicate on hematite surfaces and its influence on arsenic sorption. Environ Sci Technol 46:13235-13243. https://doi.org/ $10.1021 / \mathrm{es} 303297 \mathrm{~m}$

El Batal H, Abdelghany A, Hassan M, Abdelaziz T, EzzElDin F (2016) Effect of $\mathrm{MnO}_{2}$ doping on optical and FTIR spectra of lead phosphate glasses. Quantum Matter 5:213-218. https://doi.org/10. 1166/qm.2016.1290

El-Naggar A, El-Naggar AH, Shaheen SM, Sarkar B, Chang SX, Tsang DCW, Rinklebe J, Ok YS (2019) Biochar composition-dependent impacts on soil nutrient release, carbon mineralization, and potential environmental risk: a review. J Environ Manag 241:458-467. https://doi.org/10.1016/j.jenvman.2019.02.044

Essington ME (2015) Soil and water chemistry: an integrative approach. CRC Press, Boca Raton

Fang C, Zhang T, Li P, Jiang R-f, Wang Y-c (2014) Application of magnesium modified corn biochar for phosphorus removal and recovery from swine wastewater. Int J Environ Res Public Health 11:9217-9237. https://doi.org/10.3390/ijerph110909217

Hedley M, Bolan N, Braithwaite A (1988) Single superphosphatereactive phosphate rock mixtures. 2 . The effect of phosphate rock type and denning time on the amounts of acidulated and extractable phosphate. Fertil Res 16:179-194. https://doi.org/10.1007/ BF01049773

Hiemstra T, Barnett MO, van Riemsdijk WH (2007) Interaction of silicic acid with goethite. J Colloid Interface Sci 310:8-17. https:// doi.org/10.1016/j.jcis.2007.01.065

Klüpfel L, Keiluweit M, Kleber M, Sander M (2014) Redox properties of plant biomass-derived black carbon (biochar). Environ Sci Technol 48:5601-5611. https://doi.org/10.1021/es500906d

Luo H, Wang Y, Wen X, Cheng S, Li J, Lin Q (2021) Key roles of the crystal structures of MgO-biochar nanocomposites for enhancing phosphate adsorption. Sci Total Environ 766:142618. https://doi. org/10.1016/j.scitotenv.2020.142618

Mizuki K, Katoh M (2021) Phosphorus recovery from soil through phosphorus extraction and retention on material: a comparison between batch extraction-retention and column percolation. J Environ Manag 277:111435. https://doi.org/10.1016/j.jenvman. 2020.111435

Mohan D, Abhishek K, Sarswat A, Patel M, Singh P, Pittman CU (2018) Biochar production and applications in soil fertility and carbon sequestration - a sustainable solution to crop-residue burning in India. RSC Adv 8:508-520. https://doi.org/10.1039/ C7RA10353K 
Moraes CAM, Fernandes IJ, Calheiro D, Kieling AG, Brehm FA, Rigon MR, Berwanger Filho JA, Schneider IAH, Osorio E (2014) Review of the rice production cycle: by-products and the main applications focusing on rice husk combustion and ash recycling. Waste Manag Res 32:1034-1048. https://doi.org/10.1177/07342 $42 \times 14557379$

Namasivayam C, Sangeetha D (2004) Equilibrium and kinetic studies of adsorption of phosphate onto $\mathrm{ZnCl}_{2}$ activated coir pith carbon. J Colloid Interface Sci 280:359-365. https://doi.org/10.1016/j. jcis.2004.08.015

Newman JA, Schmitt PD, Toth SJ, Deng F, Zhang S, Simpson G (2015) Parts per million powder X-ray diffraction. Anal Chem 87:10950 10955. https://doi.org/10.1021/acs.analchem.5b02758

Ozcan AS, Erdem B, Ozcan A (2005) Adsorption of Acid Blue 193 from aqueous solutions onto BTMA-bentonite. Colloid Surface A 266:73-81. https://doi.org/10.1016/j.colsurfa.2005.06.001

Peng Y, Sun Y, Sun R, Zhou Y, Tsang DC, Chen Q (2019) Optimizing the synthesis of $\mathrm{Fe} / \mathrm{Al}$ (Hydr) oxides-biochars to maximize phosphate removal via response surface model. J Clean Prod 237:117770. https://doi.org/10.1016/j.jclepro.2019.117770

Peng Y, Sun Y, Fan B, Zhang S, Bolan NS, Chen Q, Tsang DC (2021) $\mathrm{Fe} / \mathrm{Al}$ (hydr) oxides engineered biochar for reducing phosphorus leaching from a fertile calcareous soil. J Clean Prod 279:123877. https://doi.org/10.1016/j.jclepro.2020.123877

Prakongkep N, Gilkes RJ, Wiriyakitnateekul W (2015) Forms and solubility of plant nutrient elements in tropical plant waste biochars. J Plant Nutr Soil Sci 178:732-740. https://doi.org/10.1002/jpln. 201500001

Santos WO, Mattiello EM, Barreto MSC, Cantarutti RB (2019) Acid ammonium citrate as $\mathrm{P}$ extractor for fertilizers of varying solubility. Rev Bras Ciênc Solo. https://doi.org/10.1590/18069657rb cs 20180072

Schwertmann U, Fechter H (1982) The point of zero charge of natural and synthetic ferrihydrites and its relation to adsorbed silicate. Clay Miner 17:471-476. https://doi.org/10.1180/claymin.1982. 017.4 .10

Shen Y (2017) Rice husk silica derived nanomaterials for sustainable applications. Renew Sustain Energy Rev 80:453-466. https://doi. org/10.1016/j.rser.2017.05.115

Sornhiran N, Tuntrachanida J, Malachey P, Thongtuk P, Wisawapipat W, Aramrak S, Prakongkep N (2021) Aluminum- and iron-engineered biochar from sugarcane filter cake as phosphorus adsorbents and fertilizers. ScienceAsia 47:220-227. https://doi.org/10. 2306/scienceasia1513-1874.2021.032

Sposito G (1980) Derivation of the Freundlich equation for ion exchange reactions in soils. Soil Sci Soc Am J 44:652-654. https://doi.org/10.2136/sssaj1980.03615995004400030045x

Szewczuk-Karpisz K, Wiśniewska M, Nowicki P, Oleszczuk P (2020) Influence of protein internal stability on its removal mechanism from aqueous solutions using eco-friendly horsetail herb-based engineered biochar. Chem Eng J 388:124156. https://doi.org/10. 1016/j.cej.2020.124156

Takaya CA, Fletcher LA, Singh S, Okwuosa UC, Ross AB (2016) Recovery of phosphate with chemically modified biochars. J Environ Chem Eng 4:1156-1165. https://doi.org/10.1016/j.jece. 2016.01.011

Thabet MS, Ismaiel AM (2016) Sol-gel $\gamma-\mathrm{Al}_{2} \mathrm{O}_{3}$ nanoparticles assessment of the removal of eosin yellow using: adsorption, kinetic and thermodynamic parameters. J Encapsul Adsorpt Sci 6:70. https:// doi.org/10.4236/jeas.2016.63007
Vikrant K, Kim K-H, Ok YS, Tsang DC, Tsang YF, Giri BS, Singh RS (2018) Engineered/designer biochar for the removal of phosphate in water and wastewater. Sci Total Environ 616:1242-1260. https://doi.org/10.1016/j.scitotenv.2017.10.193

Wang S, Gao B, Li Y, Mosa A, Zimmerman AR, Ma LQ, Harris WG, Migliaccio KW (2015) Manganese oxide-modified biochars: preparation, characterization, and sorption of arsenate and lead. Bioresour Technol 181:13-17. https://doi.org/10.1016/j.biortech. 2015.01.044

Weber B, Stadlbauer EA, Schlich E, Eichenauer S, Kern J, Steffens D (2014) Phosphorus bioavailability of biochars produced by thermo-chemical conversion. J Plant Nutr Soil Sci 177:84-90. https://doi.org/10.1002/jpln.201300281

Wei J, Tu C, Yuan G, Bi D, Xiao L, Theng BKG, Wang H, Ok YS (2019) Carbon-coated montmorillonite nanocomposite for the removal of chromium(VI) from aqueous solutions. J Hazard Mater 368:541-549. https://doi.org/10.1016/j.jhazmat.2019.01.080

Wood R, Fornasiero D, Ralston J (1990) Electrochemistry of the boehmite-water interface. Colloids Surf 51:389-403. https://doi.org/ 10.1016/0166-6622(90)80154-V

Wu LP, Zhang SR, Wang J, Ding XD (2020) Phosphorus retention using iron (II/III) modified biochar in saline-alkaline soils: adsorption, column and field tests. Environ Pollut 261:114223. https://doi.org/10.1016/j.envpol.2020.114223

Yang F, Zhang S, Sun Y, Tsang DC, Cheng K, Ok YS (2019a) Assembling biochar with various layered double hydroxides for enhancement of phosphorus recovery. J Hazard Mater 365:665-673. https://doi.org/10.1016/j.jhazmat.2018.11.047

Yang X, Chen X, Yang X (2019b) Phosphorus release kinetics and solubility capacity of phosphorus fractionation induced by organic acids from a black soil in northeast China. Can J Soil Sci 99:9299. https://doi.org/10.1139/cjss-2018-0085

Yao Y, Gao B, Inyang M, Zimmerman AR, Cao X, Pullammanappallil P, Yang L (2011) Removal of phosphate from aqueous solution by biochar derived from anaerobically digested sugar beet tailings. J Hazard Mater 190:501-507. https://doi.org/10.1016/j.jhazmat. 2011.03.083

Yao Y, Gao B, Chen JJ, Yang LY (2013) Engineered biochar reclaiming phosphate from aqueous solutions: mechanisms and potential application as a slow-release fertilizer. Environ Sci Technol 47:8700-8708. https://doi.org/10.1021/es4012977

Zhang M, Gao B (2013) Removal of arsenic, methylene blue, and phosphate by biochar/AlOOH nanocomposite. Chem Eng J 226:286292. https://doi.org/10.1016/j.cej.2013.04.077

Zhang M, Gao B, Yao Y, Xue Y, Inyang M (2012) Synthesis of porous $\mathrm{MgO}$-biochar nanocomposites for removal of phosphate and nitrate from aqueous solutions. Chem Eng J 210:26-32. https:// doi.org/10.1016/j.cej.2012.08.052

Zhang M, Gao B, Varnoosfaderani S, Hebard A, Yao Y, Inyang M (2013) Preparation and characterization of a novel magnetic biochar for arsenic removal. Bioresour Technol 130:457-462. https:// doi.org/10.1016/j.biortech.2012.11.132

Zheng YL, Gao B (2019) Reclaiming phosphorus from secondary treated municipal wastewater with engineered biochar. Chem Eng J 362:460-468. https://doi.org/10.1016/j.cej.2019.01.036

Zheng Y, Zimmerman AR, Gao B (2020) Comparative investigation of characteristics and phosphate removal by engineered biochars with different loadings of magnesium, aluminum, or iron. Sci Total Environ 747:141277. https://doi.org/10.1016/j.scitotenv. 2020.141277 


\section{Authors and Affiliations}

\section{Natcha Sornhiran ${ }^{1} \cdot$ Surachet Aramrak ${ }^{1}$. Nattaporn Prakongkep ${ }^{2} \cdot$ Worachart Wisawapipat $^{1,3}$}

$\triangle$ Worachart Wisawapipat worachart.w@ku.th

1 Department of Soil Science, Faculty of Agriculture, Kasetsart University, Bangkok 10900, Thailand

2 Land Development Department, Office of Science for Land Development, Bangkok 10900, Thailand

\section{Research Network of NANOTEC-KU on NanoCatalysts} and NanoMaterials for Sustainable Energy and Environment, Kasetsart University, Bangkok 10900, Thailand 